Cahiers de recherches médiévales

Journal of medieval studies

$12 \mid 2005$

La tradition épique, du Moyen Âge au XIX ${ }^{\mathrm{e}}$ siècle

\title{
The epic tradition of Charlemagne in Italy
}

Jane E. Everson

\section{(2) OpenEdition}

Journals

Electronic version

URL: https://journals.openedition.org/crm/2192

DOl: $10.4000 / \mathrm{crm} .2192$

ISSN: 1955-2424

\section{Publisher}

Honoré Champion

\section{Printed version}

Date of publication: 30 December 2005

Number of pages: 45-81

ISSN: 1272-9752

Electronic reference

Jane E. Everson, "The epic tradition of Charlemagne in Italy", Cahiers de recherches médiévales [Online]

12 | 2005, Online since 30 December 2008, connection on 15 December 2022. URL: http://

journals.openedition.org/crm/2192 ; DOI: https://doi.org/10.4000/crm.2192

This text was automatically generated on 15 December 2022.

All rights reserved 


\title{
The epic tradition of Charlemagne in Italy
}

\author{
Jane E. Everson
}

\section{Introduction}

1 From the late thirteenth century to the end of the Renaissance, Carolingian narratives centred on the deeds of Charlemagne, Roland and the peers of France enjoyed immense popularity in Italy at all levels of society. Some of the greatest writers of this period were attracted to the genre and produced in it their masterpieces. And if, for the early period, the most important compositions are often anonymous, for the fifteenth and sixteenth centuries the names of Andrea da Barberino, Pulci, Boiardo, Ariosto and Tasso, to name only the best known and most influential, serve to underline the status of Carolingian narrative literature as the pre-eminent literary genre in the vernacular. As I have pointed out elsewhere, the sheer length of time during which the Carolingian narrative tradition flourished in Italy, the large number of writers involved with the genre, the wealth of material both in content and style, the range of developments and modifications, all pose major problems for the scholar aiming to produce a comprehensive historical and thematic survey of the genre. ${ }^{1}$

2 The magnitude of the task had already taxed E. G. Gardner at the beginning of the twentieth century and Sir Anthony Panizzi at the beginning of the nineteenth. It is perhaps scarcely surprising, therefore, that the history of Carolingian narratives in Italy, while highly desirable, still effectively remains to be written. ${ }^{2}$ Inevitably therefore a survey article like the present discussion can paint only the broad outlines and trace only the major steps in the development of Carolingian narratives in Italy. Regrettably but unavoidably much will be omitted that in a larger context would naturally be included. The aim therefore will be to focus on the verse narratives in the vernacular which have as their core themes the epic struggles of Charlemagne against the Saracens, and the deeds (gesta) of Roland, the peers of France and their chief pagan antagonists. While maintaining a chronological approach, the discussion will aim to 
emphasise the most significant modifications and innovations of the Italian tradition as well as key aspects of continuity.

\section{Historical overview}

3 The narratives of Charlemagne, Roland and the peers of France are first attested in Italy in the form of sculpted reliefs dating from the twelfth century, in baptismal records and in various place names. ${ }^{3}$ The earliest literary records of the tradition date, however, from the later thirteenth century. ${ }^{4}$ At this period chansons de geste were being regularly recited in Italy, and at least as far as northern Italy is concerned, were being copied in the original French by Italian scribes. Chansons de geste in French continued to be copied for Italian audiences until into the fifteenth century, again especially in the Po valley where a certain bilingualism in the reception of such texts persisted long after texts ceased to be produced in French. ${ }^{5}$ From the early fourteenth century, however, new compositions begin to emerge, still in the traditional form of laisses, but in hybrid linguistic forms known as Franco-Italian or Franco-Venetian. These narratives originate especially in the Po valley and in particular the areas around Padua and Verona. South of the Apennines in Tuscany, where the linguistic influence of Dante and Boccaccio was obviously strongly felt, the narratives passed into Italian by the mid-fourteenth century at the same time as the new metre of ottava rima was invented and imposed itself as the fundamentally important vehicle of Italian narrative poetry. Though the influence of Dante is paramount in terms of language, it is Boccaccio who had the greater influence on the development of vernacular narratives of Charlemagne, both through his own vernacular epic in ottava rima, the Teseida, and through his brilliant demonstration of the powers of vernacular prose. ${ }^{6}$ In the course of the fourteenth century Carolingian narratives develop in prose in Tuscany and reach their apogee with the work of Andrea da Barberino in the early fifteenth century. ${ }^{7}$ This simultaneous existence of, and interaction between, vernacular prose accounts and verse narratives within the Carolingian narrative tradition makes tracing the textual transmission of a particular narrative very complex. Andrea's work of compilation stands, however, as something of a watershed; thereafter the prose tradition becomes much less significant in terms of new compositions. Subsequent writers drew significantly on Andrea's work, but it was the narrative in ottava rima which became, in the fifteenth to sixteenth centuries, the vehicle of the Carolingian tradition in Italy. From the mid-fifteenth century to the mid-sixteenth century Italy saw the greatest flowering of the vernacular narrative derived from the chansons de geste paradoxically, since this was also the context of the great flowering of the revival of classical culture, of the Renaissance. ${ }^{8}$ To this period, nonetheless, belong the poems of Pulci, Boiardo and Ariosto, the significant contributions of other court poets and second rank writers, and the vigorous continuation of the cantari by anonymous figures. The popularity and vigour of the whole tradition can best be measured in the number of titles in the genre produced in the period between 1470 and the end of the sixteenth century, and the frequency with which individual titles were reprinted. ${ }^{9}$ After the middle of the sixteenth century, however, the changed cultural and political climate had already begun to spell the decline of the genre and its definitive retreat into purely popular levels of culture after a period of two centuries of innovation and 
experiment in which it had occupied a prominent place at the most sophisticated levels of high culture. ${ }^{10}$

\section{The early and popular tradition}

E del mio Carlo imperador m'increbbe;

Ché so quanti la penna ha posti in cima,

Che tutti la sua gloria prevarrebbe:

È stata questa istoria, a quel ch'io veggio,

Di Carlo, male intesa e scritta peggio. (Morg. I, 4)

4 When Luigi Pulci began his Morgante, at the behest of the mother of Lorenzo dei Medici, in about 1461, narratives on the subject of Charlemagne, Roland and the peers of France had been being produced in Italy for almost two hundred years, and the stories themselves, in the original French versions, had been known for even longer. Nevertheless, in spite of such a long and well-established tradition, Pulci (and his patron) had much justification for considering that Charlemagne had not been well served by writers in Italy. Before he sets out on his literary re-writing of the story of Charlemagne, Pulci briefly rehearses the popular tradition he is about to replace. He does so by mentioning Charlemagne's knights by name, confident that his listeners, sophisticated or otherwise, will be able mentally to supply for themselves the adventures of these well-known figures. His list is thus a useful synopsis of the Carolingian tradition of the past two hundred years in the Italian peninsula. The allusions include elements common to all Carolingian traditions -Turpin, Gano- and others more specific to Italy -the battle at the abbey of San Liberatore at Manopello near Chieti for example, and the myth of Florence's refoundation by Charlemagne. The narrative opens at Charlemagne's court:

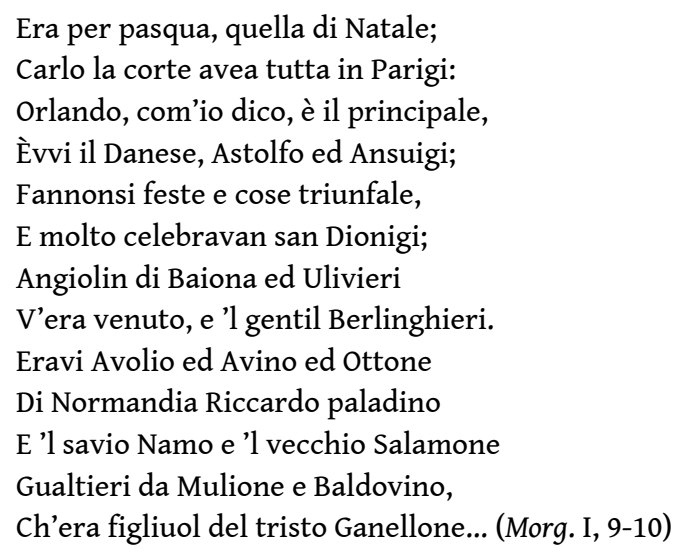

5 And immediately Gano provokes a dispute, protesting at the fact that everyone has to obey Orlando -himself, Namo, Ottone, Uggieri and Salamone among others- and this has been so since Aspremont, when Charlemagne attributed victory to the young Orlando and not, as Gano asserts was really the case, to Gherardo di Vienna. Pulci thus expects his audience to be well acquainted not only with the story of Aspremont, but also with the tales of Ogier, Girard de Rousillon, Gerard de Vienne among others. 


\section{Transmission and reception}

6 Pulci, his patrons and his audience would have known of the various epic cycles recalled here, and indeed of others equally absorbed and rewritten into the great Renaissance narrative poems of the later fifteenth and sixteenth centuries, through both oral and written forms. Evidence for oral transmission is haphazard but continuous from the late thirteenth century through the comments of those who heard recitations in public as well as those who gave such recitations. ${ }^{11}$ The frequency and popularity of such recitations is also well attested, but equally gives rise to difficulties in tracing the precise transmission of individual epics, the point at which innovations and modifications were introduced, and the consequent stemma for any one text. Many of the epic stories in the early period probably existed only in skeletal or outline form (much like the later commedia dell'arte scenarios) as prompt books for the reciter who would then fill in, from memory, the details of the episodes. ${ }^{12}$ In consequence, although versions of the epics, in Italian, were certainly circulating in the fourteenth century, few manuscripts of fully Italian language versions survive from before the first half of the fifteenth century. Such comments are important when one examines the surviving written versions and in attempting to understand the crucial developments adduced in the course of the fourteenth century.

7 As far as the written tradition of Carolingian epic is concerned, as has frequently been observed, a central role was played by the emergence, again from the late thirteenth century onwards, of the northern Italian city-states, dominated by powerful families: Gonzaga, Visconti and Este in particular. In spite of the violence and strife that dominated Italy in the fourteenth century, the leading members of these families, from an early date, collected books and constituted libraries, of both vernacular and classical texts. Above all, as the library records reveal, they had a particular interest in the vernacular romances and epics of the French tradition, an interest which endured to the end of the Renaissance..$^{13}$ It is through the catalogues of these libraries that the written tradition of Carolingian epic in Italy has normally been traced for the period between the end of the thirteenth and middle of the fifteenth centuries, but to assume that the texts contained in these manuscripts constitute the source texts for all subsequent narratives on a particular epic theme is to ignore important regional and linguistic distinctions within the peninsula. ${ }^{14}$ Though the Franco-Venetian versions of the exploits of Charlemagne, Roland, Buovo, and Ogier that these texts transmit undoubtedly circulated throughout the Po valley, it cannot be assumed that they were current south of the Apennines in this same linguistic garb or indeed with the same precise emphases and contents. Moreover it is certainly the case that verse narratives in assonanced laisses (and in Franco-Venetian) were still being actively composed and rewritten north of the Apennines when in Tuscany Italian and the new ottava rima metre had already replaced the older metrical form. ${ }^{15}$ Nevertheless in terms of chronology it can be stated that an independent tradition of Carolingian epic in Italy may be said effectively to have begun with the copying of manuscripts of popular French narratives, by Italian scribes, for these princely libraries.

8 The most significant of these manuscripts, dating to the end of the thirteenth or beginning of the fourteenth century are those formerly in the possession of the Gonzaga family in Mantua and now at the Marciana library in Venice. ${ }^{16}$ Of these V4 and V7 transmit versions of the Chanson de Roland; V6 and V7 the Aspremont. The most 
interesting for the subsequent tradition, since it contains the largest number of different texts, is V13. This manuscript contains narratives concerning Charlemagne, Roland, Buovo and Ogier le Danois, texts collectively known as the Geste Francor. ${ }^{17}$ These texts are the composition of a single narrator-scribe. Though fundamentally transmitting French narratives, even if in hybrid linguistic forms, the versions of the Geste Francor show significant differences in certain respects in the elaboration of the narrative by comparison with the French originals. Indeed the texts have been rightly described as: "un rifacimento abbastanza libero di canzoni francesi" and provide early evidence of Italian modifications to the tradition. ${ }^{18}$

Equally of interest, especially for the development of the Carolingian tradition in Italy, are the subsequent fortunes of these individual narratives. Those concerned with the childhood of Charlemagne, and with the troubled fortunes of the older Berta, seem not to have given rise to native Italian verse compositions. Though knowledge of these narratives is often assumed, in particular the explanations they provide for the origins and enduring hostility of the Maganzese clan towards the Chiaramontesi, there are no surviving ottava rima poems on the childhood of Charlemagne or on Berta, nor did any such poems make the crucial transition into print. Narratives of the childhood of Orlando (and tales of his parents, the younger Berta and Milone) on the other hand had a greater appeal, not least given the tradition, already present in the V13 texts, of Orlando's birth in Italy and the Italianisation of his name which forms a part of the story. Similarly the campaigns in Aspremont were to prove popular in Italy, in view of their Italian location. The remaining tales, those of Ogier and of Buovo, reveal a striking contrast from the point of view of later developments and popularity. Ogier, italianised as Uggieri, continued to be an important protagonist in Italian narratives, both prose and verse (ottava rima), in the course of the fourteenth century, but by the fifteenth century that independence has been eclipsed. Uggieri has become by this time no more than one of the group of knights around Orlando, the companion of Rinaldo, Ulivieri and Astolfo, and frequently of less prominence than these: such is his role in Pulci's Morgante, reflecting the principal source on which Pulci is drawing. ${ }^{19}$ Narratives centred on Buovo d'Antona, on the other hand, enjoyed a tremendous popularity right through until the end of the sixteenth century. These narratives, on themes independent of those based on the deeds of Orlando and Rinaldo, made the transition into print very early -evidence of their popularity and of demand by the public- and significantly also the Buovo narratives are one of the few for which dedicated woodcut illustrations were produced: an honour shared only with Pulci's Morgante until series began to be produced for the Furioso in the later 1520s. ${ }^{20}$

\section{Spagna and Rencesvals}

10 In terms of both antiquity of transmission and enduring appeal, the pre-eminent narrative strand of Carolingian epic in Italy is that of Roland and the military campaigns and adventures with which he is associated, culminating in the final battle at Rencesvals. Although depending very largely on the same Franco-Italian intermediaries, the history of this narrative tradition is most conveniently divided into two: the Aspromonte strand, dealing with narratives of Roland's early career; and the Spagna strand, dealing with his mature career and death. This latter may be seen as 
constituting the oldest Italian Carolingian narrative tradition, since it can be traced in artefacts dating to the twelfth century. ${ }^{21}$

Early written evidence of knowledge of the Chanson de Roland narrative is provided in two forms relating to the two essential aspects of transmission: writing and reception. In the early fourteenth century, Dante, at several points in the Commedia, mentions Roland and the defeat at Rencesvals. Roland is first referred to in Inferno XXXI, 16-18, where Dante draws on the account of his death at Rencesvals for a comparison with the terrible sound of Nimrod's horn which he hears as he descends into the pit of Hell.

Dopo la dolorosa rotta quando

Carlo Magno perdè la santa gesta,

Non sonò sì terribilmente Orlando.

The phrase is echoed by Pulci, in his own introduction, in Morgante I, $8 .^{22}$ Already in Dante Roland appears with the standard Italian version of his name, and the elliptical reference suggests an assumption of familiarity by Dante on the part of his public with the famous episode.

Shortly afterwards, Dante, appropriately, refers to Ganelon, in Inferno XXXII, 122, among the traitors. ${ }^{23}$ Gano is thus the archetypal traitor -to country, family and religion- for Dante and for his public. Dante's allusions to the Carolingian epic tradition are completed in Paradiso XVIII, 41-48, where Roland himself, together with Charlemagne, William of Orange and Rainouart, appear in the Heaven of Mars as examples of holy warriors martyred in defence of the Christian faith. Though brief, it is clear from Dante's lines that knowledge of Carolingian epic was already widespread in Italy. As Viscardi indicates, ${ }^{24}$ Dante's knowledge, like that of his public, derived in large part from oral recitations; but in the case of educated and literate individuals, like Dante, also from written accounts. What precise versions of the narrative of the battle of Rencesvals Dante knew remains uncertain. Viscardi suggests that these would have been predominantly prose accounts and summaries, but it is equally possible in the case of Dante, given his residence during his exile in the courts of northern Italy, that he had access to versions related to those preserved in the manuscripts formerly in the Gonzaga library.

The first genuinely Italian contribution (as opposed to the passive activity of copying manuscripts of pre-existing texts) to the Spagna cycle is constituted by the Entrée d'Espagne, a landmark not only in the transmission and development of Carolingian epic in Italy but of Italian literature as a whole. ${ }^{25}$ The anonymous author, who describes himself as a Paduan, was clearly an educated, cultivated individual, probably a cleric, as is evident in the content of his narrative. His innovations do not extend to language and metre -since the Entrée is composed in assonanced laisses and in a form of French current in north-east Italy (Franco-Venetian), but the scope of his narrative is vast and his aims and intentions complex and interesting. The poem opens with Charlemagne in Aix deciding on the expedition to Spain and then covers the invasion, campaigns against Marsilie, and the sieges of Najera, Noble and Pamplona. At this point, Roland and Charlemagne quarrel, over the expedition against Noble, and this provokes Roland's desertion and departure to the East, where he becomes a mercenary captain in the service of the Sultan. A lacuna in the text, of several thousand lines, probably contained the narrative of the liberation of Jerusalem and the conversion of the Sultan. In the last, surviving section, Roland returns to Spain and is reconciled to Charlemagne. 

Rencesvals, provoking the question: is the poem incomplete, or intentionally openended? Traditionally critics have considered the poem unfinished, pointing to the continuations that soon followed: the additional section and the Prise de Pamplune, of Niccolò da Verona, and the Rotta di Roncisvalle. But open-ended narratives are a central and consistent feature of the Italian Carolingian epic tradition, whose texts frequently point forward to the culmination of the war at Rencesvals, as the end of the story, but do not necessarily narrate the final battle. Moreover a very recent, detailed analysis of the Entrée suggests that the poem is in fact complete according to the poet's aims and his conception of the poem's structure and scope. ${ }^{26}$

Between the Entrée of the early fourteenth century, and Pulci's Morgante of the midfifteenth, the Spagna narrative tradition developed in complex ways. The original Franco-Italian tradition continued to be narrated and read in northern Italy until well into the fifteenth century, as is evident from library holdings and commissions for copying of manuscripts, ${ }^{27}$ but alongside this developed a genuinely Italian language tradition in which the contamination between prose and verse referred to above is particularly apparent. The Entrée d'Espagne itself was followed most immediately by the Prise de Pampelune of Niccolò da Verona. ${ }^{28}$ Niccolò's poem, which aims to complete what he sees as the unfinished narrative of the Entrée, introduces into the history of Carolingian epic in Italy a standard feature of that literary tradition -the poem of continuation and completion of a preceding narrative. The tradition which begins with Niccolò da Verona is still vigorously flourishing at the beginning of the sixteenth century when Niccolò degli Agostini, among others, attempted to complete Boiardo's unfinished Orlando Innamorato. ${ }^{29}$ Even an apparently definitively completed narrative such as the Orlando Furioso in turn spawned continuations, centring on the offspring of Ariosto's protagonists or on secondary characters. ${ }^{30}$ The Prise de Pampelune in fact does not complete the story of the campaigns in Spain, and its innovative contribution to the developing tradition is perhaps less striking. It is still composed in Franco-Venetian, and in assonanced laisses, and it springs from much the same environment, geographically and culturally, as its greater predecessor, the Entrée. Nevertheless Niccolò's poem further asserts what Vidossi calls, "l'elemento nazionale italiano", evident for example in the introduction of a new hero, Desiderius, and the participation of the Lombards in the campaigns in Spain, which results in their being granted independence. ${ }^{31}$

Between the mid-fourteenth and the mid-fifteenth centuries Italian narratives concerning Charlemagne's campaigns in Spain were actively elaborated, but the history of these texts and their mutual influences on each other remains obscure and in part insoluble. The oldest surviving manuscripts of an Italian, ottava rima, Spagna narrative are datable only to the second quarter of the fifteenth century, but as Catalano rightly argues, the relationships traceable between these, and the extent to which they contain different versions of the same episodes, for example, indicate that they cannot possibly be the first or earliest ottava rima Spagna versions..$^{32}$ Though the fifteenth-century, ottava rima versions certainly reveal the contamination of the prose accounts, which in some cases date from the later fourteenth century, once again not all the narrative material derives from these prose versions. ${ }^{33}$ Furthermore the narrative account of the Entrée alone is not sufficient to account for all the diverse material of the fifteenthcentury poetic versions. ${ }^{34}$ The fully elaborated, fifteenth-century version, of 40 canti,

Cahiers de recherches médiévales, 12 | 2005 
narrates the whole story of the Spagna campaigns from the initial planning of the invasion of Spain by Charlemagne, in order to confer a kingdom on Orlando, through the quarrel between Charlemagne and Orlando, and Orlando's adventures in the East, Orlando's return to Spain after the conversion of the Sultan and the capture of Pamplona, and finally the battle of Rencesvals. The Spagna in rima thus also synthezises the developments which have been introduced into the Carolingian tradition in Italy in the course of the fourteenth century, in particular in characterization, emphasis and incorporation of originally extraneous material.

Pulci was almost certainly familiar with the Spagna in rima in its fifteenth century versions, and with the earlier prose and verse accounts which it elaborates, but he draws on this tradition only for the final five canti of his poem. The most immediate source for the first and longer part of Il Morgante is an ottava rima poem now known as the Orlando laurenziano, a popular cantare datable to the first half of the fifteenth century, of which the Morgante is a close but dynamic rewriting. ${ }^{35}$

\section{Aspremont}

19 The same lacunae of manuscript evidence and the same contaminations between prose and verse texts characterize the narratives concerned with Orlando's early career, the Aspromonte narrative strand. Unlike the Spagna narratives, however, where the Entrée d'Espagne constitutes a new and original composition by an Italian author which, while maintaining the established metre and language, develops the source narrative in distinctive and unforeseen ways, there is no such innovative Italian epic of the Aspremont extant. ${ }^{36}$ The earliest surviving narrative of the Aspromonte strand composed in Italian is the Cantari di Aspramonte, in ottava rima and in Tuscan, which thus belongs to the next stage of development of Carolingian epic in Italy ${ }^{37}$ Like the Spagna narratives, the Cantari di Aspramonte, of 23 canti, draw not only on earlier poetic versions, but also on the late fourteenth-century prose version, though not, apparently, on Andrea da Barberino's fifteenth-century compilation of the same narrative. ${ }^{38}$

In the course of the fifteenth century the Aspromonte narrative continued to be well known, but among the more educated principally through the prose of Andrea da Barberino rather than through the popular cantari. ${ }^{39}$ Pulci, Boiardo and Ariosto all allude to the events and campaigns of Aspremont, maintaining the tradition of Aspremont as the place where Orlando had achieved his first significant victories, defeated Agramante's predecessors and won his sword Durlindana, but they do not attempt to rewrite the account of these campaigns. ${ }^{40}$ As far as verse narratives on this theme are concerned, the fifteenth century saw a gradual withering of interest among the Italian public, surprisingly given the location of Aspremont and the topicality of Turkish incursions in southern Italy in the later fifteenth century. ${ }^{41}$ The earliest printing of the Cantari in Beer's census is 1491, which is late by comparison with many texts in the genre, and she records only nine for the whole of the sixteenth century. ${ }^{42}$

\section{Guillaume and cycle d'Orange}

Pulci's list of the knights gathered at Charlemagne's court, quoted above, also contains some significant omissions, of which perhaps the most striking is that of Guillaume 
d'Orange and his kin. As noted above, Guillaume had been emphatically recalled by Dante in Paradiso XVIII, both through his own name and through that of Rainouart; clearly for Dante the deeds of Guillaume d'Orange, and possibly the whole cycle, was perfectly familiar. And yet as the conflicting views of the early, fourteenth-century commentators on the Commedia reveal, this familiarity could not be taken for granted..$^{43}$ Though cantastorie recitations on the subject of Guillaume are attested, by the early fourteenth century the popularity of such narratives was already declining. ${ }^{44}$ The cycle d'Orange narratives appear not to have been composed in ottava rima, a fact which undoubtedly contributed further to their eclipse in the poetic tradition of Charlemagne in Italy; certainly there are no printed poetic tales of Guillaume and his family. Only the prose Storie nerbonesi of Andrea da Barberino continued to keep alive knowledge of this protagonist and his clan. ${ }^{45}$ It is indeed striking, in view of the large number of poems belonging to the cycle d'Orange in the French tradition, that they should occupy so small a place in the Italian Carolingian tradition.

\section{Reynaud/Rinaldo}

Another equally striking omission from Pulci's list is the name of Rinaldo da Montalbano, but this has nothing to do with lack of familiarity or popularity. Indeed Rinaldo is an important figure in Il Morgante. In contrast with the disappearance of narratives about Guillaume and the cycle d'Orange, or those in which Uggieri was protagonist, narratives centred on the adventures and exploits of Rinaldo da Montalbano enjoyed an ever increasing popularity in Italy from the later fourteenth century. By the fifteenth century Rinaldo had usurped Ulivieri's role as Orlando's closest associate and counterpart. Pulci still preserves a certain balance between Rinaldo and Ulivieri, and frequently portrays both acting in concert with Orlando, but Ulivieri scarcely figures in either Boiardo's Orlando Innamorato, or Ariosto's Orlando Furioso. In these poems Rinaldo frequently seems to leave behind his characteristic past as rebellious baron par excellence, highwayman and robber chief when necessary, and, though still prone to amorous passions, to become increasingly the figure of the rational man, mature, sober, worldy-wise, the dependable military captain, the righthand man of Charlemagne and his principal general, a striking contrast to the increasingly unstable and eventually insane Orlando: it is an impressive and even unexpected transformation. Yet the original appeal of Rinaldo for an Italian public surely lay in his defiance of imperial authority, of the claims of an overlord, and in his less than heroic attitudes and behaviour on many occasions, his practical, pragmatic and entrepreneurial outlook which increasingly reflected Italian milieux. Rinaldo's rise to popularity is paralleled by the decline in the status and character of Charlemagne as emperor. Caught between his inability to perceive the treacherous machinations of Gano against Rinaldo, Orlando and their relatives, on the one hand, and, on the other, his incapacity to control or restrain the rebelliousness of the lord of Montalbano, Charlemagne emerges, in particular in the poems in which Rinaldo is the protagonist, as weak, petulant and childish: one of the adjectives most characteristically applied to him is rimbambito.

The earliest Italian verse narrative on Rinaldo is represented by the Cantari di Rinaldo da Monte Albano, datable, on Melli's analysis, to the late fourteenth century. ${ }^{46}$ The Cantari $d i$ Rinaldo, of 51 canti, are thus considerably longer than the fifteenth-century Spagna in 
rima and twice the length of the almost contemporary Cantari di Aspramonte. Here too, as in the case of the Aspromonte narratives, there is no single, extant, early fourteenthcentury Franco-Italian poem on the subject of Rinaldo. Nevertheless the story of the Quatre Fils Aymon, and of Rinaldo in particular, was both well known and is attested through a variety of records. ${ }^{47}$ As Melli points out, the Cantari di Rinaldo certainly draw on the French narrative traditions of Beuve d'Aigremont, of Maugis, and of Renaut de Montauban, as well as reflecting elements of narrative traditions present in the FrancoVenetian manuscripts, such as that of Macaire. ${ }^{48}$ This parentage serves to reinforce the point made above about the different sources on which the Tuscan and the Venetian storytellers of the fourteenth to fifteenth centuries are drawing. At the same time a comparison between individual episodes of the Rinaldo narrative as related in the Cantari and in the French accounts is revealing of the extent to which the narratives concerning Rinaldo have already, by the late fourteenth century, undergone substantial modifications.

\section{The legacy of the fourteenth century}

The legacy of the fourteenth century to the Carolingian tradition of epic in Italy can be summed up, as the preceding survey suggests, under two principal headings: modifications to the material narrated; and the development of the new metre of ottava rima. The combined influence of these two was to ensure not just the transmission of the tradition of Carolingian epic into the high Renaissance, but also its prominence and popularity at all levels of society and culture, in particular its appeal to an elite audience, and hence the involvement of major authors in the composition of poems in the genre. As far as the incorporation of new material is concerned, while it is possible to establish certain broad tendencies, many of the modifications are particular to the individual writer and work. On the one hand, virtually all texts reveal the withering away of the obligations and structures of feudalism and crusade, and a change, often a decline, in the role of the Emperor. On the other hand, the extent to which a poem incorporates motifs from Arthurian romance, or attempts to locate itself within the milieu of humanism and the revival of classical culture may vary considerably. In contrast, the adoption of the metre of ottava rima acts as a unifying factor for the genre, in which poets continually build on and react to the use of the ottava by predecessors and rivals, in a continual process of refinement which reaches its apogee, though in two quite distinct ways, in the poems of Ariosto and Tasso. ${ }^{49}$

\section{Ottava rima: the key to success}

The significance of the invention of the ottava rima for the success of the vernacular epic in Italy cannot be overestimated. ${ }^{50}$ Traditionally the invention of this metre was ascribed to Boccaccio, who uses it with considerable expertise in both the Filostrato (ca 1335) and the Teseida (1340-41). The latter, which is Boccaccio's attempt to write classical epic in the Italian vernacular, is certainly significant for the subsequent fortunes of both the metre and vernacular epic; its popularity is attested by the existence of a commentary on it from the early fifteenth century, and by the large number of extant manuscripts from the period, and its early appearance in print. ${ }^{51}$ Boccaccio's Teseida draws also on the tradition of Arthurian romance, and it is possible 
that it was the prior existence of short poems of this tradition in the new metre which led Boccaccio to use ottava rima rather than Dante's terza rima for his epic. Certainly cantari on Arthurian topics are recorded for the 1330s, and may even in one or two cases be datable to the 1320 s. $^{52}$

Boccaccio and the Teseida are an important influence on the vernacular epics of the fifteenth century, but the adoption of the metre for Carolingian epic can also be attributed to other factors and influences, in particular in Tuscany. A major influence certainly can be ascribed to the cantari of Antonio Pucci. ${ }^{53}$ Although most of these are short, and mix themes from Carolingian, Arthurian and novella traditions, as well as contemporary events, their success and popularity could hardly have escaped the notice of cantastorie. Nor should one underestimate the appeal, again especially at this date for a Tuscan public, of a metre so well adapted to exploiting the particular characteristics of the Italian language, and indeed developing these further. No Tuscan of the fourteenth century was immune to the dynamic demonstration of the vigour and flexibility of the language provided by Dante's Commedia, and, after the mid-century, by the writings of Boccaccio. Moreover ottava rima clearly had an appeal not just to cantastorie and their audiences in the piazza, but equally to more educated and cultivated readers and writers. Already by mid-century educated writers (if not great poets) are producing poems on the epic matter of Rome aimed at least in part at a moderately educated public: Domenico Scolari's Istoria Alexandri Magni is dated in the manuscript to 1355; Domenico Montichiello's Troiano to circa 1350, and versions in ottava rima of the Aeneid and the Pharsalia appeared in the last quarter of the century. ${ }^{54}$ These, which, however indirectly, draw on and aim to reflect the classical epic tradition, provided a clear stimulus for poems in the principal vernacular epic tradition, of Charlemagne and Roland. These, as we have noted, were already being composed before the end of the fourteenth century, as far as the Aspramonte and Cantari di Rinaldo are concerned, and almost certainly, though the evidence is lacking, in respect of the Spagna stories. What remains unclear is at what point narrative poems in ottava rima crossed the Apennines and displaced the long-standing northern tradition of compositions in Franco-Venetian laisses. Clearly this was well-established by the 1430 s, and gathered pace in the 1450s when Borso d'Este, for example, had narratives on both Carolingian and Arthurian themes translated from French to Italian. ${ }^{55}$ There is ample evidence for the oral tradition of recitation of cantari and the circulation of cantastorie in Tuscany for the fourteenth century, but much less precise information about the recitation of ottava rima north of the Apennines. Yet given the contacts between states, and, for example, the residence of Tuscan exiles in northern Italy, it seems plausible to posit knowledge of and interest in ottava rima narratives in northern Italy from the mid-fourteenth century. ${ }^{56}$

\section{The flowering of the vernacular epic}

The period from the mid-fifteenth to the mid-sixteenth centuries marks the apogee of Carolingian epic in Italy. In this period the vernacular epic of Charlemagne abandons the cloak of anonymity of author becoming instead the proving ground for major writers and the supreme demonstration of their literary talents. A rich set of variations on the Carolingian epic and its themes runs from Pulci in the mid-fifteenth century to Tasso at the end of the sixteenth, and embraces writers of many and varied abilities, 
from Ariosto and Tasso as the supreme exponents, through Boiardo, Cieco, and Bernardo Tasso, to those whose enthusiasm for the genre far outstripped their poetic abilities. Out of the rich inheritance of the fourteenth and early fifteenth centuries prose as well as verse, oral as well as written, Arthurian and classical as well as Carolingian, poets and writers drew according to their individual preferences, and created in their individual works their own recipe for Carolingian verse epic. It would be impossible even in a much longer survey to analyse all of the poems which merit consideration, and I shall therefore concentrate here on four examples which, in addition to their literary merit, illustrate well the diversity present in the genre during the Italian Renaissance: the poems of Pulci, Boiardo, Cieco and Ariosto.

\section{Pulci57}

Pulci's aim, as quoted above, is to rewrite the history of Charlemagne, and in particular the crowning moment of Charlemagne's literary glory, the battle of Rencesvals, and to do so in a sophisticated and stylish way. Eventually Pulci does make good this promise, in the final three cantos of the Morgante. The bulk of his poem, however, does not deal with these matters. Pulci is early on diverted from this aim by his sources, his Florentine environment, and his own interests and inclinations. Indeed when the Morgante first appeared it did not narrate the battle of Rencesvals at all, stopping short, at c. XXIII, with the narrative of the deeds of Rinaldo and the converted Fuligatto in the middle East. Only after a gap of several years, and through the encouragement of fellow writers, in particular Poliziano, did Pulci return to his material and finish the story in accordance with his original aim. ${ }^{58}$ Pulci's struggle to narrate the battle of Rencesvals is significant and constitutes a turning point in the development of the genre. Prior to this date, as the Spagna in rima demonstrates, poets had had no difficulty in carrying the narrative up to its definitive conclusion, even if the narrative took a long time, and many twists and turns to reach that point. After Pulci, none of the major exponents in the genre narrates the battle of Rencesvals. Was it just too far away in time and place? Or is the solution rather that after Pulci warfare, in the form of the French invasions, came just too close to home for an Italian public? Certainly one should apply to this striking development the Dionisottian paradox. ${ }^{59}$ In a world in which the French were the aggressors and their greed and brutality more in evidence than heroism and the defence of the faith the celebration of the noble sacrifice, by French heroes, at Rencesvals was problematic.

A part of Pulci's problem over Rencesvals was constituted by his principal source, the anonymous cantare known as the Orlando laurenziano. ${ }^{60}$ This poem narrates the exploits and adventures of Orlando and his friends, especially Rinaldo and Ulivieri, mainly in the Middle East. In this cantare, as was traditional by the mid-fifteenth century, elements of adventure, romance, the novella tradition, marvels and monsters predominate over the serious epic struggle, and Pulci follows this lead. ${ }^{61}$ From the Orlando Pulci takes the character of the giant Morgante, who becomes the companion of Orlando after Orlando has defeated and killed Morgante's brothers, and converted Morgante. Orlando has left Charlemagne's court after a quarrel with Gano, and in the Morgante, as in the Orlando and indeed the Cantari di Rinaldo and the Spagna in rima, much of the subsequent action depends on the machinations of Gano, his vast network of spies and his repeated attempts to make trouble for Orlando and his companions, 
and even to bring about their deaths through some form of treachery rather than in battle. Like Orlando, Rinaldo too leaves Charlemagne's court in search of Orlando and driven out by Gano's lies. At various points in the narrative Orlando, Rinaldo and Ulivieri all fall in love with Saracen princesses -but these are fleeting if passionate relationships and usually end badly for the lady. Morgante dies, in a mock heroic incident, after being bitten by a crab (XX, 31-51).

From one perspective Pulci follows the source poem closely. At times he reuses not just the material but words and phrases too, and yet the Morgante is a very different poem from the Orlando, marked by the inclinations of the author and the Florentine and especially Medici environment in which he was operating. In the 1460s, when Pulci was writing his poem, he was already a close associate and member of the inner circle around Lorenzo, a participant in the youthful pastimes and interests, as well as the more intellectual pursuits of Lorenzo. Those activities included, on the one hand, the serious philosophical debates of the Accademia Platonica gathered around Marsilio Ficino, and the intense engagement with humanist and classical culture which had dominated Florentine intellectual circles from the beginning of the century and was to be renewed vigorously when Poliziano joined Lorenzo's household in 1473; and, on the other, an enjoyment and an adoption of rustic and carnevalesque culture. Pulci himself was not a sophisticated intellectual or leading humanist scholar, but he was deeply attracted to new ideas, especially to those which challenged the status quo. His fascination with pagan philosophies, magic and astrology surfaces in the Morgante through his mockery (probably intended playfully rather than destructively) of Christian doctrine and Christian practice, which is most apparent in two extensive passages entirely invented by Pulci: the encounter of Morgante with Margutte (Morg. XVIII-XIX), and the dialogue of Rinaldo with the devil Astarotte (XXV). ${ }^{62}$

31 The carnevalesque dimension of Pulci's writing, evident also in his other works, is apparent in the Morgante in particular through his use of language and in the humorous emphasis given to many episodes, words and actions. The dominant presence of the giant Morgante fighting by naturally unchivalrous means, and the down-to-earth practicality that he brings to the business of fighting are carnevalesque. The burlesque behaviour of Orlando and his companions, so far removed from the serious (or dull) portraits of earlier narratives, are similarly a part of Pulci's humorous approach to his material -and one which creates problems in the transition to the last five canti, in which Orlando must emerge as the noble and serious hero of Rencesvals.

The first version of the Morgante, of 23 cantos, was printed in 1478 and met with great success, but it did not escape the notice of his public that the poem was effectively incomplete. Subsequently Pulci returned to his poem, completing it by drawing on the material of the Spagna in rima to narrate his version of the "Rotta di Roncisvalle". The effort to link the last five cantos into the preceding poem can be traced in stanzas at the end of XXIII and the beginning of XXIV, but the shift in tone cannot be hidden. Nevertheless, despite Pulci's reluctance to narrate the battle of Rencesvals, his version of the story, in these five canti, is notable for various distinctive features: the emphasis placed on Charlemagne as Emperor; the incorporation of new characters; and the association of the Christian knight Rinaldo with the devil Astarotte and their joint role as "saviours" at Rencesvals. striking, in view of the portrait painted by Pulci earlier in the poem, and indeed the 
general picture of the Emperor conveyed in the Italian tradition. ${ }^{63}$ This reassertion of the role, dignity and character of the Emperor is, however, intimately linked to Pulci's Florentine milieu. Charlemagne had long been considered the second founder of Florence, endowing it afresh with a classical Roman (or neo-Roman) origin. This theory of the refoundation of Florence was strongly present in Pulci's milieu and had been given fresh impetus by a new life of Charlemagne, by Donato Acciaiuoli. ${ }^{64}$ The reevaluation of Charlemagne and the stress laid on a more historical picture of the Emperor are especially to be found in the final canto of the Morgante. It must be associated too with the classicizing culture in which Pulci is writing and the increasing drive within that culture to imitate and surpass classical literary models including epic. Since classical epic celebrated the deeds of great heroes and founders -for which the chief model was Virgil's Aeneas- understood as history not legend, and moreover as local history, Charlemagne as second founder of Florence emerged as an obvious protagonist. Indeed Charlemagne as founder of a city and not the progenitor of the ruling family matched Florence's republican traditions, and the Medici fiction of themselves as citizens not "signori" admirably. ${ }^{65}$

When Pulci at last begins the narrative of the battle at Rencesvals, in XXVI, the traditional players are all certainly present: Orlando, Ulivieri and Turpin, on the Christian side; Marsiglio and Bianciardino, on the pagan Saracen side. To these Pulci adds others, some of his own invention entirely, and some from other strands of the tradition -Rinaldo and Ricciardetto, Astolfo and Malagigi. Rinaldo, brought especially to Rencesvals as a result of the prophetic insights of Malagigi and his manipulation of devils, emerges finally as the hero of the battle. The account of the battle is shot through with irony and contradictions, which circumscribe the sense of tragedy. The traditional behaviour of Orlando -his refusal to summon help by blowing his horn- is ironically exposed as pointless adherence to tradition, since in spite of his refusal, help arrives unsummoned in the form of Rinaldo as deus (or perhaps diabolus) ex machina. Orlando's death is played out at some length, as Pulci imports elements of the contemporary "sacre rappresentazioni" into the narrative, together with overtones of Dante, as Orlando, assured of his apotheosis, is also assured that he will find his dear companion Morgante in heaven, but not of course Margutte, who has an important role in the other place (Morg. XXVII, 138-40).

\section{Boiardo 66}

The composition of the Orlando Innamorato was stimulated in part by the evident success of Pulci's undertaking, but also by the environment of the court of Ferrara, of which Boiardo was an important member. ${ }^{67}$ Like the Morgante, it was composed in two, possibly three distinct phases, corresponding to the three books into which it is divided, and was similarly published in two different states. The first two books (60 cantos) were written mainly in the 1470 s and published in 1483; but the story of Orlando's infatuation was not complete, and soon after Boiardo began a third book. This progressed much more slowly and was left unfinished, at just eight and a half cantos, when he died in 1494. The unfinished state of the poem, and the extent of interest in the story lines developed by Boiardo sparked a series of continuations in the first half of the sixteenth century, and these, together with the circumstances surrounding the first full printing of Boiardo's own composition, created a complex 
history around the text in subsequent centuries. ${ }^{68}$ The interruptions to Boiardo's poem are closely linked to political events in Italy, in particular the outbreak of war between states, and the French invasion of 1494, what Dionisotti has described as the period of crisis for the genre in Italy -a crisis produced not by literary exhaustion but by external events with which writers in the Carolingian tradition particularly had to come to terms. ${ }^{69}$

As the title of Boiardo's poem emphasises, the main aim of the poem is to tell a story of love, a point that is reinforced in his opening stanza:

E vedereti i gesti smisurati,

L'alta fatica e le mirabil prove

Che fece il franco Orlando per amore

Nel tempo del re Carlo imperatore. (I, i, 1)

In stating his programme thus Boiardo differs significantly, not only from Pulci's purpose, but also from the whole cantari tradition. Though love had frequently figured within the tradition, and does so quite extensively in the Morgante, it had not hitherto been the primary subject and aim of a narrative in the Carolingian tradition. It is in fact curious that Boiardo, in wanting to narrate a story of love, should choose as the vehicle for that story the Carolingian epic and not the Breton romance, more especially since the latter was particularly popular at the Ferrarese court. ${ }^{70}$ The result of his choice of genre is a complex structure for the poem, one which owes much to the romance technique of entrelacement, which Boiardo uses extensively, but controls only partially effectively. Frequently indeed the material of the narrative seems to dominate the poet, rather than the poet to be in command of his narrative; digressions, episodes, and even close repetitions of stories are all features of the Innamorato. In addition, and contributing to the sense of complexity, Boiardo is not content with just one theme of war and one of love and interweaving these. The Orlando Innamorato contains no fewer than four narratives of war, at least two of love, and a completely new theme, that of the founding of the dynasty of his patrons, the Este.

In constructing the narratives of war, Boiardo reveals the very diversity of the literary influences operating on him. The first narrative, begun at the beginning of book I, is that of Gradasso, king of Sericana (India). This owes much to the tradition of romances of Alexander the Great and the more fantastic tales of travellers to the East, from Herodotus onwards. ${ }^{71}$ The motives of Gradasso in his invasion of France are those of a romance quest: he desires to possess Orlando's sword and Rinaldo's horse:

Così bramava quel pagan gagliardo

Sol Durindana e 'l bon destrier Baiardo. (I, i, 5)

The second theme of war is introduced almost immediately afterwards, when Angelica arrives at Charlemagne's court. This is first presented as a campaign to overthrow Charlemagne by the Tartar king Galafrone, who intends to achieve this through magic, enchantment and fraud, for which purpose he has sent Angelica and her brother ostensibly to take part in the tournament in Paris (I, i, 24-29; 36-40). This purpose is overturned when both Christian and pagan knights and kings, all infatuated with Angelica, arrive at Albraca in central Asia and take part, on one side or the other, in the siege of the city (I, ix, 38-41). Angelica's challenge when she arrives at Charlemagne's court for the tournament has undeniable romance origins, while the location of Albraca and the campaigns in those regions once again reveal the influence of the Alexander romances and the tales of mythical Greek heroes, Jason and Hercules in particular. Yet the various knights, Christian and pagan, gathered in Paris for the tournament are 
those of the Carolingian tradition, those recalled by Pulci, and familiar from the popular cantari: Ferraguto, Balugante, Serpentino; Salamone di Bretagna; Rinaldo, Orlando, Malagigi and of course Gano; and those whose names are drawn to fight against Argalia (Angelica's brother) include Astolfo, Dudone, Berlinghieri, Ottone, as well as, for the pagans, Ferraguto and Grandonio. ${ }^{72}$ It is these knights of the Carolingian tradition whom Boiardo uses to respond to the typical Breton romance challenge issued by Angelica and around whom he builds the principal narrative of love.

The third narrative of war is introduced at the beginning of book II and this is much more directly and firmly linked to the Carolingian epic tradition. At the end of book I, Boiardo, rather like Pulci, restrains his narrative verve, reminding himself, and his reader, of the need to concentrate on Charlemagne and the properly epic struggles of the Christian emperor against Saracen invaders (I, xxix, 55-56). The invasion of France by Agramante, which constitutes this third narrative of war, derives directly from the Aspromonte tales, since Agramante is the grandson of Agolante, and son of Troiano (II, $i, 14$ ) and his motive in launching the invasion is the traditional one of vengeance for the death of his predecessors. The Carolingian link is emphasised by reference to the history of Ruggiero da Risa, and by the reiteration (II, i, 49-51) by Sobrino of the previous victorious exploits of the paladins. Yet here too Boiardo is unable to dissociate himself from the twin influences of Breton romance and classical mythology. Agramante's palace, in which he is presented, is frescoed with the exploits and campaigns of Alexander the Great and his successors, among whom Agramante counts himself. Through the mention of Ruggiero da Risa, Boiardo also provides the basis for his dynastic theme, whose literary origins lie rather in classical epic.

41 The fourth narrative of war opens the third book of the Innamorato, though neither the campaign of Gradasso, nor that of Agramante, has been concluded. Led by Mandricardo, son of Agricane king of Tartary, who has been killed by Orlando in book I, this unites the two motives of Gradasso and of Agramante, since it is both a campaign of vengeance for the death of his father, and a quest, for the arms and armour of Orlando (III, i, 5-14). Though the death of Agricane in Orlando Innamorato book I reflects, and derives from, the famous duel of Rolando and Ferragu in the Entrée d'Espagne, and so links Mandricardo into the pure Carolingian tradition, it is the romance element of his campaign that is dominant from the start: he leaves quite alone and unaccompanied, and is soon entangled in a romance adventure after entering a tent pitched by a fountain (III, i, 15).

Boiardo's unease with the narratives of war is clear from the difficulties he finds in giving space to descriptions of battles and campaigns, and in bringing any of them to conclusion. The siege of Albraca is eventually simply abandoned (II, xviii), while the other three war narratives are all still incomplete when the poem was left unfinished. It was thus left to Boiardo's continuators, including Ariosto, to conclude these narratives.

As is clear, it is love and the adventures, quests and enchantments associated with that romance theme that attract Boiardo and inspire his poem. The modifications to the characters of the paladins, and especially of Orlando, consequent upon such an emphasis, constitute one of the chief innovations of the Innamorato. Though Orlando had frequently fallen in love in earlier poems, and indeed in Il Morgante, these had been fleeting passions, not a persistent and unchanging infatuation with one woman. Boiardo's initiative radically changes the character of Orlando and significantly affects the whole subsequent tradition. In constructing the new Orlando, Boiardo combines the 
old tradition of Orlando's strict adherence to chastity and lack of interest in women with the vulnerability of the inexperienced in love and an unwavering conformity to the dictates of chivalry towards women. That Angelica is unworthy of such devotion is clear from the outset of the poem, where she is introduced as deceitful and manipulative (O. I. I, i, 36-40). Orlando's exaggerated reverence for her is thus presented as foolish and ridiculous, as is emphasised by the cruder and much more self-interested reactions of Ferraguto and Malagigi, for example (0. I. I, i, 45-47, 70). His strict application of the code of chivalry towards all women leads him into further ridicule and even danger (in the encounter with Origille for example, O. I. I, xxix). This is a portrait of Orlando that is strikingly different from Pulci's. The Orlando of the Morgante is still able to make fun of lovers and tease Ulivieri, for example, for his infatuations. Boiardo's Orlando has, it seems, no sense of humour or self-irony, and is thus already on the path to the insanity into which Ariosto leads him by the middle of his poem.

In the Innamorato the chief foil to Orlando is Rinaldo (called Ranaldo by Boiardo), and here too Boiardo overturns the expectations of tradition. Rinaldo (like Astolfo) was famous in the Italian tradition for his amatory escapades, but in the Innamorato, after an initial coup de foudre for Angelica, shared with all present, Rinaldo drinks from Merlin's "fontana dell'odio" and conceives an intense hatred for Angelica. Such an inversion is already productive of humour for an Italian public, but Boiardo further enhances it by causing Angelica to drink from "la rivera dell'amore" and to conceive an indomitable passion for Rinaldo (I, iii). Thus Boiardo constructs that perennial literary topos, a love triangle of unrequited lovers which persists for much of the poem, giving rise to both humour and moments of tension, including a fierce duel between Rinaldo and Orlando (O. I. I, xxvi-xxvii).

The developments in the characters of Orlando and Rinaldo introduced by Boiardo are matched by the characterization of the figure of the female warrior. The increasing importance and interest shown to the figure of the virago in the Italian narrative poems constitutes another very significant development in the genre from the later fifteenth century on. It is a development that owes most to the recuperation of the ideals and aims of classical epic, of the Aeneid especially, and to the reappropriation and reuse of Greek mythology in all spheres of culture. Yet in spite of this derivation from "high" culture, the beautiful and indomitable female warrior also rapidly captured the popular imagination, becoming central to several late fifteenth-century cantari, and titular heroines in the period following the publication of Ariosto's poem, in the midsixteenth century. ${ }^{73}$ The most notable and most popular of these female warriors was Bradamante, introduced within the Italian tradition during the fifteenth century as sister of Rinaldo and sometimes twin of Ricciard(ett)o. ${ }^{74}$ Yet, though Boiardo selects her to be the female protagonist of his dynastic theme, he would seem to have difficulty writing about a character who must be simultaneously very feminine and very martial. Her appearances in the Innamorato are quite restricted. Boiardo is much more at ease in writing about his other virago, Marfisa, eventually to be revealed as Ruggiero's longlost sister, and daughter, therefore, of Galaciella (herself a female warrior). ${ }^{75}$

Boiardo's other principal innovation into the tradition is the dynastic theme based on the characters of Ruggiero and Bradamante. The Carolingian tradition in Italy had not previously incorporated this classical theme, though poems had, like Pulci's, been dedicated to patrons. In introducing the dynastic theme Boiardo was principally influenced by the revival of classical culture, and the traditions of imitation and 
emulation which the re-reading of classical texts inspired. The dynastic theme of Virgil's epic had already been incorporated into the neo-Latin epics of the Renaissance, beginning with Petrarch's Africa, and, continuing, very close to Boiardo personally, with Tito Vespasiano Strozzi's Borsiad, in praise of Borso d'Este. ${ }^{76}$ Other reasons which may have inspired Boiardo to introduce this classical theme into the vernacular epic may have included: the fashion for Renaissance princes to establish descent from a mythical, preferably Trojan, hero; the need for the Este family to affirm the legitimacy of its rule both against family rivals and against other states; Boiardo's own classical reading and interests; and perhaps most forcefully of all, as I have argued elsewhere, the need for the vernacular narrative tradition, inherited from medieval France to maintain and enhance its position in the literary firmament, in particular among the more educated readers, in a world in which the fashion was for classical and classicizing culture..$^{77}$ In his presentation of the dynastic theme, Boiardo achieves a nice fusion of classical and Carolingian traditions. Ruggiero and his antecedents are first rehearsed, by Sobrino, in the environment of Agramante's palace which is decorated with scenes from the life of Alexander, and in certain details, here and later, Ruggiero's destiny is based on that of Achilles. But Sobrino's presentation of him recalls his parents, Ruggiero di Risa, and Galaciella, his converted Saracen wife, daughter of Agolante. Later, in III, v (18 ff), when Ruggiero introduces himself to his future wife, the female warrior Bradamante, the emphasis falls first on the classical origins, now his descent from Hector, and then, as he traces the subsequent generations, the Carolingian traditions of the Reali di Francia and Buovo d'Antona (ibid. 29ff). ${ }^{78}$

\section{Pagan protagonists: Mambriano}

An important feature of Carolingian narratives as they developed in the cantari of the fifteenth century was the choice of pagan protagonists and titular heroes, some, but by no means all of whom, convert to Christianity within the narrative. These tales were clearly popular, and were frequently printed up to and including during the later sixteenth century ${ }^{79}$ Many of these demonstrate little imaginative flair or originality, and little talent in manipulating the ottava rima. Nevertheless it is not the case that all such narratives were the work of poor and anonymous cantastorie; several of the authors came from the educated and even courtly classes, and several were in receipt of some form of princely patronage. Of this group of poems the most significant, and probably also the best in terms of its literary and stylistic qualities is Il Mambriano of Francesco Cieco da Ferrara.$^{80}$ Little is known of Cieco's life, but it is clear from what is said in the poem and from the sparse archival material on him that at the time of the composition of the Mambriano (1490-1502) he was in turn a member of the court circles in Bozzolo, Mantua and Ferrara, in receipt of patronage from members of the Gonzaga and Este families. The poem appeared in print in 1509, after Cieco's death, and in a number of subsequent editions until the mid-century. It was highly regarded by contemporary critics, who listed it alongside the poems of Pulci, Boiardo and Ariosto, and was probably drawn on by Tasso. ${ }^{81}$

The importance of the Mambriano lies both in the period and environment in which it was written, and in its contents and innovations. Cieco began writing in the period between the publication of the first two books of Boiardo's Orlando Innamorato and before the continuation of the story in his third (and, as it turned out, unfinished) book. 
Boiardo himself had in part been stimulated to begin the Innamorato by the success of Pulci's Morgante and the desire of his patron and lord Ercole d'Este that the achievements of Ferrara in this genre should surpass those of Florence. That same sense of rivalry and emulation in the genre almost certainly influenced Cieco and his Gonzaga patrons. Both Pulci and Boiardo had shown ways of breathing new life into the old stories, incorporating contemporary culture into their poems. Boiardo in particular had emphasized elements of classical epic (the dynastic theme) and Breton romance, but his experiment remained incomplete. The popularity of vernacular epic was emphasized, not only by the interest of princely patrons, but also by its commercial success in the market for printed books.

The final decade of the fifteenth century and the early years of the sixteenth were nonetheless a challenging period for the genre. The conflict between a literary tradition which portrayed the French as heroes, and reality, in which they were invaders and aggressors, produced an unavoidable crisis. Boiardo had recognized defeat, some months before his death, unable to reconcile the two. A decade later, and in spite of continuing hostilities, Ariosto took up the story and made it his own, for a new patron and in changed circumstances. Between 1494 and 1505, however, the fortunes of Carolingian epic hung in the balance..$^{82}$ These are the years in which the greater part of the Mambriano was composed, and it is for that reason that the poem occupies a major place in the history of the genre in Italy. In spite of all the difficulties created by the environment Cieco composed a Carolingian epic of note, one which drew on the old traditions of the cantari, but equally on the culture of the courts in which he worked; a poem which consistently demonstrates an awareness of the innovations introduced by Pulci and Boiardo and adds some of Cieco's own.

The titular hero of the poem, Mambriano, is a nephew of Mambrino and his brothers. Cieco thus links, loosely but clearly, his principal theme to the narratives of Rinaldo and his family, which had become the most popular of the Carolingian narratives in Italy. Mambriano invades France in order to avenge his relatives who have fallen in battle against Rinaldo. His first attempt at invasion is disastrous; after a shipwreck in which he loses his entire fleet, he is ensared on the island of Carandina, a figure of Circe. When she discards him in favour of Rinaldo, he is rescued by his countrymen, who inform him that his own kingdom has been usurped in his absence. This somewhat buffoonish approach to invasion and warfare may be said to set the tone for all the subsequent campaigns of the poem. Mambriano's second invasion initially has some success, due to the absence of both Rinaldo and Orlando, but the opposition of the Christian forces led by Rinaldo's sister Bradamante prevents any decisive victory. When Rinaldo returns to France, through Malagigi's stratagems, the Christians move on to the offensive. Mambriano retreats to his own, Middle Eastern, kingdom, pursued by Rinaldo and the forces of Charlemagne. In the battles that follow the two most significant forces are, on the pagan side, a group of giants with their unorthodox weapons, and on the Christian side, Malagigi the magician and conjuror of demons. ${ }^{83}$ The clash of Christians versus pagans is enhanced here by the rivalry in love of Rinaldo and Mambriano, both of whom remain infatuated with Carandina. The campaigns end with the comprehensive defeat of Mambriano, who must pay tribute to Charlemagne, and the marriage of Mambriano and Carandina. In tandem with the campaigns of Mambriano and Rinaldo, Cieco narrates the campaigns of Orlando and Astolfo in north Africa, which culminate in the defeat of the Africans and the wholesale conversion of Utica to Christianity. After further adventures, both Orlando and Rinaldo and their 
companions return to Charlemagne's court for celebrations and jousting (XXXV). This is, however, not the end of the story. At an early stage in the poem, Orlando has made a vow to go to Compostella. Now he is led to fulfil this vow, and on the way liberate the road to Compostella from various brigands and robber barons and usurpers. ${ }^{84}$ Rinaldo's son Ivonetto is given a prominent role following the joust, in the episode of Uriella and "il novo Meleagro" (XXXVI-XXXVII), which borrows from both classical and Breton traditions; while in the final cantos Rinaldo reverts to his traditional role of highwayman, robbing passers-by to pay his troops, because his spendthrift ways have led him into poverty -a plight from which, in the last episode of the poem, he is rescued by another of Malagigi's tricks (XLV).

51 The extent to which Cieco gathers up and reproposes themes from the long tradition of the cantari (and their prose counterparts) can only be evident from a detailed analysis of the whole poem, but is not in itself surprising. Much more significant are the innovations which Cieco makes, some of which are subsequently taken up by his immediate successor, Ariosto. These innovations include the characterization of the female warrior, Bradamante, the characterization of Gano, the incorporation into the narrative of free-standing novelle, and the dramatic use of the opening stanzas of each canto as a privileged space for the poet. ${ }^{85}$

52 Female knights had appeared extensively in the Morgante, but in every case there they had also been seen essentially as objects of desire to male warriors, both pagan and Christian, and frequently responsive to those desires. Boiardo had presented the figure of Bradamante, sister of Rinaldo, and indicated that she would be the progenitor of his patrons, the Este family, but her role in his poem is very restricted. By the time she appears in Ariosto's Furioso, her role and personality are fully developed: the key to that development lies in Cieco's Mambriano. In this poem Bradamante is not only an indomitable fighter; she is also, as she will be for Ariosto, one of Charlemagne's chief generals, and in the absence of Rinaldo and Orlando, commander-in-chief. She is, as in Boiardo, extremely attractive, and as with Pulci's female warriors, finds herself the object of desire on several occasions, but unlike all those previous models, she herself has no interest in men. Rather she has a series of techniques and stratagems for avoiding any involvement, ranging from crude insults (as against Mambriano, VI, 55-57) to humorous tricks and mockery (in the case of the elderly Pinamonte, XV, 50-56; 70-76). ${ }^{86}$ Indeed it is in the latter case that Cieco establishes the challenge which suitors of Bradamante must overcome -namely that they must defeat her in a duel and that she will not give herself to anyone who is not militarily her superior- a challenge which Ariosto adopts and enhances in the final stages of his poem. ${ }^{87}$ Cieco does not make Bradamante the future progenitor of his patrons, nor indeed indicate any future husband for her. After a brief suggestion early in the poem that the virtuous pagan, Sinodoro, might fill this role, he seems to have abandoned the idea of a dynastic theme. Cieco's Bradamante is distinctive too in that she is the only female warrior in the poem; her role thus acquires a greater prominence for being unique.

53 The portrait of Bradamante given by Cieco develops out of hints in preceding narratives, which Cieco then refines and isolates to create his special figure of the female warrior. His portrait of Gano also derives from tradition, but in this case Cieco's approach is decidedly revolutionary: his Gano becomes no longer the arch traitor but rather a loyal companion of Rinaldo who uses his literary reputation as a traitor to trick Mambriano and the pagans. This playfulness with such an established tradition on 
the part of Cieco introduces a strikingly postmodern note into his poem, but it also leaves Gano in some senses still as the archmanipulator and alter ego of the poet: both Rinaldo whom Gano and his tricks benefit, and Mambriano who is defeated by them are the playthings of Gano and could, if circumstances changed, find their positions reversed. In the prominence given to Gano, Cieco distinguishes himself in various ways from Pulci, Boiardo and Ariosto.

The seven novelle contained within the narrative of Il Mambriano are the part of the poem which subsequently attracted most attention from both readers and critics. These novelle were frequently printed as popular pamphlets from the sixteenth to the nineteenth centuries, and were the subject of critical studies both of the novella as a genre, and for the sources on which they draw. ${ }^{88}$ The incorporation of novelle into the verse epic is another of the distinctive characteristics of the fully developed Italian narrative poem. Although the process is not initiated by Cieco in the Mambriano - it is already found in Boiardo's Orlando Innamorato - it is used by Cieco in particular ways. In the Innamorato, as later in Ariosto's poem, novelle inserted into the texture of the poem are closely linked into the main narrative, either through the active involvement of one of the principal characters, as in Rinaldo's involvement in the later stages of the tale of the Rocca di Altaripa (O. I. I, viii), or through the absorption of the protagonists of the novella into the main narrative at the conclusion of the episode, as in the case of Boiardo's novella of Prasildo and Iroldo (O.I I, xii). ${ }^{89}$ In the Mambriano, on the other hand, incorporation and involvement of these kinds is rare, affecting only the last of the seven novelle, that of Orio Doria (XXXIX-XL), who is rescued from imprisonment by Orlando and after telling his past history (the novella) proceeds to accompany Orlando on the pilgrimage to Compostella. All of the preceding six novelle are free-standing, told for the entertainment of characters, and to create a pause, a moment of relaxation for both characters and audience. ${ }^{90}$ Judging by their subsequent fortuna the most popular of these were the first, the story entitled "È fatto il becco all'oca", ${ }^{91}$ and the sixth, entitled "Le tre beffe", but all reveal the rich and bawdy dimensions of the novella tradition which had flourished so vigorously in Italy from the end of the thirteenth century. All too reveal the widely diverse sources on which the Italian novella tradition built, and the legacy of Boccaccio in the insistence on verbal wit, ingenuity, the whims of fortune, and the power of sexual attraction between men and women.

The other significant contribution of Il Mambriano to the structure of the verse epic in Italy consists in the use made by Cieco of the proemi, or opening stanzas, of each canto. From the earliest cantari in ottava rima, the proemio to the canto had been used by the reciter as a space outside the narrative. Almost invariably couched in the form of a prayer, to God or the Virgin, for inspiration with the material of the poem, the proemio might also include a brief allusion to the last episode narrated or the next to come. So strongly embedded was this tradition that the content of these stanzas was of little or no importance, and indeed their purpose was rather that of announcing the beginning of a recitation and inducing silence before the narrative itself began. Among Cieco's predecessors Pulci had continued the tradition unchanged in terms of content, but his ironic approach to all things supernatural effectively subverted the whole tradition. Boiardo had abandoned the proem based on a prayer, and instead most frequently uses the opening stanzas for a simple address to his courtly audience and a synopsis of the events of the previous canto. Though he occasionally breaks this pattern with comments on court life and culture, he seems uninterested in exploiting the 
possibilities of the proem. In contrast the proemi of the Orlando Furioso are famous for the skill with which Ariosto uses them for comments on contemporary politics, culture and war, the praise of his patrons, and above all as the space where the mask of the poet pronounces on various moral matters, and on love. In the Furioso, moreover, the link between proemio and canto is one of theme and tone not narrative details. Here too, as with the characterization of Bradamante, Cieco's Mambriano provides the key to the development between Boiardo and Ariosto. The proemi of the Mambriano fall into several categories: seasonal, especially spring openings, derived from lyric tradition; allusions to contemporary events; classical invocations; addresses to the patron; and the presentation of the mask of the poet. In drawing on the lyric tradition and the topoi of the return of spring in his proemi Cieco reveals yet another aspect of the crossfertilization and contamination between genres to which we have frequently referred. This importing of topoi from lyric poetry into the proemi is highly innovative and has at times misled critics in their attempts to date the composition of the poem..$^{92} \mathrm{Few}$ of these topoi should be used as factual evidence; they are rather a demonstration by the poet of his skill in another genre and his perception of the use that can be made of lyric motifs to renew the proemio of the narrative poem. When Cieco does allude to contemporary events, it is not through seasonal openings. Frustratingly for the dating of the poem, his allusions, principally to contemporary warfare, are much more vague than those of Ariosto subsequently, and shot through with literary reminiscences, principally from Petrarch. ${ }^{93}$ Nevertheless, such allusions mark an important stage in the development not only of the proemio but of the verse narrative as a whole, and significantly influenced Ariosto's proemi on similar matters, which are not only more explicit, but deliberately link fictional and real warfare, proem and poem. By far the most lively of Cieco's proemi, however, are those in which he dons the mask of the poet-reciter - a self-mocking figure, a buffoon, a clown, but also a poet in touch (if humorously) with the gods on Olympus, appealing for their help and talking familiarly with them, a figure comparable to those of the burgeoning comic theatre. ${ }^{94}$

Cieco ends his poem with an envoi:

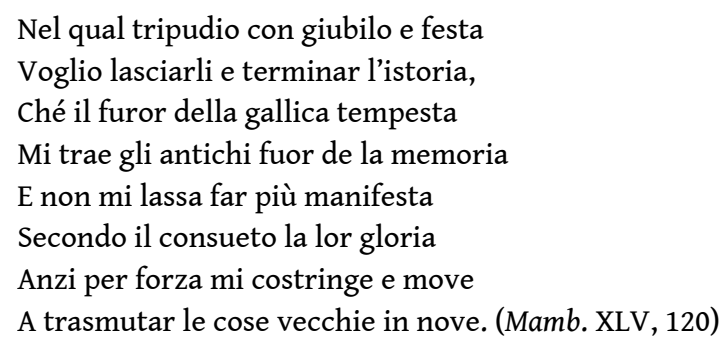

These lines, probably penned in 1501-2, and certainly no later than 1505, pertinently reflect the changed world of the turn of the fifteenth to sixteenth centuries, encapsulating neatly the paradox referred to by Dionisotti. But they also throw out a challenge - to write the old stories in a different way. It was a challenge to which Cieco himself could not respond, but which was taken up, as he metaphorically laid down his pen, by the last and greatest exponent of Carolingian epic in Italy - Ludovico Ariosto. Indeed Ariosto took up a double challenge - not only to renew the genre as Cieco indicates, but to do so by continuing and completing Boiardo's unfinished poem. Both Cieco's challenge, and Boiardo's abandonment of his poem, were provoked by “il furor della gallica tempesta", the French invasions of Italy which began in 1494. Paradoxically these loomed larger in the literary consciousness of narrative poets than the threat from Islamic nations, even though the Turkish Empire, successor to Saracens 
and Moors as the antagonist of Christendom, remained a dominant threat throughout the fifteenth and much of the sixteenth centuries, as some poems attempted to reflect, positing narratives based around the alliance of Christendom with states to the East of the Ottoman Empire. ${ }^{95}$

\section{Ariosto $^{96}$}

The opening stanzas of the Orlando Furioso set out Ariosto's thematic programme and demonstrate quite clearly his intentions of continuing not only Boiardo's plot lines but also his fusion of epic and romance: the Furioso will narrate the campaign of Agramante, the infatuation and madness of Orlando, and the heroic exploits of Ruggiero, ancestor to Ariosto's (as to Boiardo's) Este patrons. The narrative then opens in medias res with the battle in the Pyrenees (O .F. I). Though Ariosto thus retains Boiardo's complex structure and continues to use the techniques of entrelacement to advance the different plot lines, he demonstrates, in contrast, a sophisticated and brilliant control of the material..$^{97}$ Ariosto himself uses the metaphors of weaving a tapestry and playing a musical instrument to emphasise the principles which underly his approach to composition and structure: harmony, variety, order and patterning. ${ }^{98}$ On to the formal structure of the canto, the web, with its roughly regular length, Ariosto maps the various contrasting cross threads of main themes, protagonists, secondary stories and incidents, in larger and smaller blocks interspersed and introduced by a commentary by the poet whose presence in the poem, though often ironic, is further evidence of control, of a guiding hand and overarching purpose. ${ }^{99}$

As far as Boiardo's titular theme is concerned, Ariosto takes up the narrative of Orlando's infatuation for Angelica and pushes it to its logical conclusion. Orlando's inability to distinguish the truth where Angelica is concerned, his complete absorption in the pursuit of her to the exclusion and neglect of all else, can have, as Ariosto sees, only one outcome: insanity, indeed is already insanity in nuce. The first major section of the poem devoted to Orlando portrays him in the throes of a hellish nightmare which he interprets as a vision of reality and proceeds to act upon. ${ }^{100}$ But where Orlando in Boiardo's poem had been a significant active presence, Ariosto perceives that infatuation, and even more complete madness, are sterile forms of narrative. In the Furioso, Orlando is "more absent than present" from the narrative, returning to his traditional prominence only after his return to sanity in XXXIX. Yet love remains a major theme in the Furioso through Ariosto's skilful development of other narratives of love, both of principal and secondary characters, whose trajectories and outcomes reflect and comment on the doomed love of Orlando. Equally in pursuit of Angelica, but more realistic in their perceptions and more earthy in their desires, Rinaldo, Ferrau and Sacripante all act as foils to Orlando; Isabella, Olimpia, Ruggiero and Bradamante all demonstrate what truly mutual love looks like and demands.

Another of Ariosto's structural techniques which allows him to keep control of the narrative is the creation of hierarchies within a theme. This technique is especially applied to the narrative of war. Ariosto privileges the campaign of Agramante, the most firmly Carolingian of Boiardo's three war themes, making the invasions of Gradasso and Mandricardo subordinate to that, indeed incorporating these latter two into the forces of Agramante. Their quests, for Baiardo and Durindana, thus become elements of that greater clash of arms, distractions from the ideological opposition of Christian and 
pagan: romance is subsumed into the epic rather than given an equal position with it. The dynastic theme, which Boiardo had set within the framework of Agramante's war, is retained by Ariosto, and the goal, of a dynastic marriage between Ruggiero and Bradamante, established by the older poet, is clearly announced from the opening of the Furioso (O. F. I, 4). On the slender beginnings given in the Innamorato, however, Ariosto creates his own story. His narrative of the Este ancestors pays equal attention to Bradamante as to Ruggiero; carefully differentiates between what is appropriate in the Bildungsroman of a male progenitor, and in that of a female ancestor; and brings into play contemporary ideas, a range of cultural references, and a subtle wit.

Ariosto's poem represents the culmination of a process of syncretism in the genre of vernacular epic, of the absorption of motifs and influences from preceding exponents in the genre, from other forms of literature and from the external context. From the world of the classical revival and renaissance humanism with which the vernacular epic had been fruitfully interacting for a century and a half, as has been shown, Ariosto absorbs approaches to the narrative of each of his three main themes. ${ }^{101}$ His account of the war between Charlemagne and Agramante is full of echoes of classical epic - in the narrative of the siege of Paris and the fury of Rodomonte (XIV); the night excursion, and the episode of Cloridano and Medoro (XVIII); the single combat between Rinaldo and Ruggiero (XXXVIII-XXXIX); and the final duel of Rodomonte and Ruggiero (XLVI). This classical epic approach to the serious narrative of war has the effect of ennobling the material and at the same time distancing it from Ariosto's public, making it mythical and less threatening. It is a way of overcoming the threat that defeated Boiardo and Cieco. And yet Ariosto also skilfully uses the war of Agramante to comment and reflect on contemporary warfare in sixteenth-century Italy, through an awareness of the reality of warfare: tactics, strategy and leadership; suffering, callous brutality and death. Agramante's war is thus very close and familiar. ${ }^{102}$ Classical epic is more obviously present throughout the dynastic theme, from the reiteration of Ruggiero's future early death in battle, like Achilles, from which his guardian Atlante, like Thetis, seeks in vain to protect him, through his dalliance on the island of Alcina (VI-VIII), like Ulysses with Circe, to his rescue of Angelica from the orc (X-XI), in a rewriting of the myth of Andromeda, which Ariosto here turns to bawdy comedy, to his single combat against Rinaldo and his final triumph over the opposition of Bradamante's family, and the self-appointed champion of the pagans, Rodomonte (XLIV-VI). Classical epic is present too in the visions of the future shown to one or both of Ruggiero and Bradamante, and most particularly in the first of these, which derives from, and closely recalls the descent of Aeneas to the underworld (III). The theme of Orlando's love for Angelica seems less closely linked to classical epic parallels, and is, as indicated, furthest too from the vernacular tradition. In the presentation of love as madness, which Ariosto asserts at the heart of his poem, there lurks a contemporary preoccupation with definitions of madness, possession and mental illness which reflects scholarly debates as well as the perennial fears of the public. ${ }^{103}$ Yet furor has also a classical epic dimension: Ariosto's title derives from Seneca's Hercules furens, and the myth of Hercules' destructive madness through love; the blind violence of those affected by furor, whether Orlando or Rodomonte, echoes that of Ajax, who like Orlando destroys herds and herdsmen in his fury (XXIV), and who, like Orlando, was invulnerable save in a single part of his body. which Ariosto weaves into the narrative: Alcina (Circe), Olimpia (Andromeda), 
Norandino and Lucina (the Cyclops) and the Amazons all provide evidence of this. ${ }^{104}$ These classically-based episodes, however, are balanced by episodes derived from romance - the stories of Ginevra (IV-VI), Isabella (XII-XXIX), Gabrina (XXII), the Rocca di Tristano (XXXII), the Signor (XLII-III), and Adonio (XLIII) - are indicative of the persistence of romance in the Furioso, its attractiveness to the younger Orlando poet and his audience. If some of these stories are inherited from Boiardo, many of the others show the influence of Ariosto's immediate predecessor, Cieco, and the use made in the Mambriano of the novella tradition. Thus the romance tales of the Signor and Adonio, as well as the burlesque and bawdy narrative of Fiammetta (XXVIII), and the satirical story of Lidia (XXXIV), are all virtually free-standing within the larger narrative, told for entertainment or instruction, at a momentary suspension of the main plot. More frequently, and in contrast to Cieco, Ariosto associates the secondary episodes with one or more of the major characters, integrating the episode into the main narrative, and uses the incident to reflect on the actions of the principal characters or indeed of mankind. To this end he draws not only on the traditions mentioned, but also on contemporary ideas and topics -travellers' tales and the expanding world (Orrilo, Caligorante - XV), political relationships with Eastern Europe (Leone-XLIV-V), the proper spheres of activity and the relationships of men and women (Marganorre-XXXVII)- the "querelle des femmes" -and the continuing humanist recuperation and imitation of classical literature, as well as the affirmation of Dante as a canonical author (Astolfo on the Moon - XXXIV-V).

In all of this manipulation of the material it must be asked how much remains of the old Carolingian tradition within which, through the choice of protagonist, the poem is ostensibly set. The Furioso has no character of Gano, nor indeed any archetype of the traitor, though it will be through the house of Maganza, so it is prophesied, that Ruggiero will eventually die. The action does not depend on a network of spies sent out by Gano to cause trouble wherever Orlando and his companions might be. Orlando for most of the poem is a lone and lonely figure, unaccompanied by his traditional companions. Rinaldo, in spite of his passion for Angelica, is no longer the figure of the perpetual rebel and robber baron, but closer to the rational man of neo-classical drama and the enlightement. Yet the Furioso opens with a battle in the foothills of the Pyrenees in which Charlemagne is defeated and his chief fighters dispersed if not killed, in a clash which cannot help but evoke the defeat in the pass of Rencesvals, and the war ends with a combat in the confined space of the island of Lipadusa between Orlando, Ulivieri and Brandimarte on the one hand, and Agramante, Gradasso and Sobrino on the other, which one critic has quite convincingly argued constitutes Ariosto's rewriting of the battle of Rencesvals. ${ }^{105}$ Moreover, the war of Agramante is presented as serious; it is an invasion of France, the heart of Charlemagne's empire in the Italian tradition and constitutes a severe threat to the whole of Christendom, epitomized in Agramante's besieging Paris itself. In this context Charlemagne becomes once more the serious and noble figure of the very earliest tradition; weakened by the absence of his chief generals, Orlando and Rinaldo, but the defender of Christendom against the pagans and the elect of God, who responds to Charlemagne's desperate prayers. ${ }^{106}$ Ariosto has not altogether abandoned the old tradition, but the narrative is set in a new world and for an audience with different concerns and values. 


\section{Conclusion}

\section{In the conc:}

... Ariosto stood at the end of a specific tradition of development of the romance epic, to which belonged also Pulci, Boiardo, and Cieco, a line of development that was distinct from the cruder cantari and anonymous popular narratives... (p. 350)

In my discussion there, which is concerned with the attempt by these authors to come to terms with, and to effect a symbiosis with the dominant classicizing culture of their times, it was appropriate to make such a distinction. In the context of the present discussion, however, suitably amended, the statement remains valid. Ariosto stood at the end of a history of development of the vernacular epic to which belonged, and to which had contributed, not only Pulci, Boiardo and Cieco, but also Niccolò da Verona and the anonymous author of the Entrée d'Espagne, the cantastorie who composed the various versions of the Cantari di Aspramonte, di Rinaldo, Buovo d'Antona, la Spagna in rima and the Orlando laurenziano, as well as the host of poets and cantastorie active in the later fifteenth century and whose works were regularly reprinted throughout the sixteenth century. The continuing attraction of the tradition is evident both in the use of vernacular epic as a school text book and in Tasso's early composition, the Rinaldo. ${ }^{107}$ But Folengo, from whom my judgement is derived, was both correct and prescient. ${ }^{108}$ The literary, cultural and political environment after the middle of the sixteenth century was different from that which had prevailed in the previous centuries. The tensions and ultimately the refusal to carry forward the epic of Roland are evident in the debates contained in Tasso's critical discourses. ${ }^{109}$ His choice of the crusades as the material for his Gerusalemme liberata undoubtedly owes something to the French Cycle des Croisades as well as to medieval chronicles, but that cycle had not played a significant part beforehand in the Italian Carolingian tradition, and must be the subject of another study.

\section{NOTES}

1. I take up here many of the topics raised, and more fully elaborated in J. E. Everson, The Italian Romance Epic in the Age of Humanism. The Matter of Italy and the World of Rome, Oxford, Oxford University Press, 2001. For the early history of the Carolingian tradition in Italy see ibid. ch. 2; for the developments and modifications introduced in particular in the fifteenth century, see chs 6-8; and for the popularity of the genre, see especially ch. 5 .

2. E. G. Gardner, Dukes and Poets in Ferrara: A study in the poetry, religion and politics of the fifteenth and early sixteenth centuries, London, Constable, 1904; Id., The King of Court Poets: a study of the work, life and time of Ludovico Ariosto, London, Constable, 1906; A. Panizzi, Orlando Innamorato di Bojardo: Orlando Furioso di Ariosto: with an essay on the romantic narrative poetry of the Italians: memoirs and notes by Antonio Panizzi, 8 vols, London, William Pickering, 1830. See also F. Foffano, Il poema cavalleresco, Milan, Vallardi, n.d. For a briefer synthesis, see H. Krauss, "Aspects de l'histoire poétique de Charlemagne en Italie”, Charlemagne et l'épopée romane. Actes du VII congrès 
international de la Société Rencesvals, Liège, 28 Aug-4 Sept 1976, 2 vols, Paris, Belles Lettres, 1978, I, p. 103-123. The most recent history of the genre is M. Villoresi, La letteratura cavalleresca. Dai cicli medievali all'Ariosto, Rome, Carocci editore, 2000.

3. See P. Rajna, "L'onomastica italiana e l'epopea carolingia", Romania, 18, 1889, p. 1-69; Id., "Altre orme antiche dell'epopea carolingia in Italia", Romania, 26, 1897, p. 34-73; A. D'Ancona, "Le tradizioni carolingie in Italia", in Saggi di letteratura popolare, Livorno, 1913, p. 1-44; A. Rossellini, "Onomastica epica francese in Italia nel medioevo", Romania, 79, 1958, p. 253-267.

4. These are constituted by the manuscripts now in the Biblioteca nazionale marciana, Venice, discussed below.

5. Evident for example in the holdings of, and borrowings from the libraries of the Visconti, Gonzaga and Este families, for which see the discussion, notes and bibliography in J. E. Everson, The Italian Romance Epic, p.139-156; for the catalogues and studies on the Este library, see especially G. Bertoni, La biblioteca estense e la coltura ferrarese, Turin, Loescher, 1903; see also discussion below.

6. The Teseida is dated around 1340-41; see Il Teseida delle nozze d'Emilia, ed. A. Limentani, Milan, Mondadori, 1992. Boccaccio's vernacular literary production runs from ca 1335 (Filostrato) to 1365, depending on the dating of the Corbaccio.

7. See Romanzi dei Reali di Francia, ed. A. Mattaini, Milan, Rizzoli, 1957. For modern critical studies on Andrea da Barberino, see in particular G. Allaire, Andrea da Barberino and the language of chivalry, Gainesville, Fla, University Press of Florida, 1997.

8. This paradox is the central theme of my study, The Italian Romance Epic, cit.

9. See M. Beer, Romanzi di cavalleria. Il "Furioso" e il romanzo italiano del primo Cinquecento, Rome, Bulzoni, 1987.

10. At popular levels of culture the tradition of Carolingian narratives persisted until well into the twentieth century, both through popular printings and through the Sicilian pupari -the travelling puppet theatre which now survives only for tourist purposes. Though the modern media are generally held to have caused the definitive decline of Carolingian epic at popular levels, certain elements of the narrative tradition persist, for example in the cinema; see A. Pasqualino, Le vie del cavaliere. Dall'epica medievale alla cultura popolare, Milan, Bompiani, 1992.

11. See for example the comments of Lovato Lovati quoted in E. Levi, I cantari leggendari del popolo italiano nei secoli xiv e $x v$, supplement no. 16, Giornale storico della letteratura italiana, Turin, Loescher, 1914, and discussion of this topic by G. Folena, "La cultura volgare e l'Umanesimo cavalleresco nel Veneto", in V. Branca (ed.) Umanesimo europeo e Umanesimo veneto, Florence, Sansoni, 1963, p. 141-158, sp. p. 142; A. Balduino, "Letteratura canterina", Boccaccio, Petrarca e altri poeti del Trecento, Florence, 1984, p.57-92; and the boasts of the anonymous cantastorie of the Serventese di tutte le Arti, for which see P. Rajna, "Il Cantare dei cantari e il Serventese di tutte le Arti", Zeitschrift für Romansiche Philologie, 2, 1878, p. 425-533.

12. On this see the valuable comments of A. Balduino, "Letteratura canterina", p. 58-61, 73-74.

13. See in particular my discussion in The Italian Romance Epic, ch. 5, p. 151-156, and Id., "Read what I say and not what I read: reading and the romance epic in fifteenth-century Ferrara", Italian Studies, 58, 2003, p. 31-47.

14. See G. Bertoni, La biblioteca estense, cit.; Id., "Lettori di romanzi francesi nel Quattrocento alla corte estense", Romania, 45, 1918-19, p. 117-122; P. Girolla, "La biblioteca di Francesco Gonzaga secondo l'inventario del 1407", Atti e memorie della Real Accademia Virgiliana di Mantova, 14-16, 1923, p. 30-72; W. Braghirolli, "Inventaire des manuscrits en langue française possédés par Francesco Gonzague I, Capitaine de Mantoue mort en 1407”, Romania, 9, 1880, p. 497-513; G. Mazzatinti, "Inventario dei codici della Biblioteca Visconteo-Sforzesca redatto da Ser Facino da Fabriano nel 1459 e 1469", Giornale storico della letteratura italiana, I, 1883, p. 33-59; E. Pellegrin, La bibliothèque des Visconti et des Sforza ducs de Milan au $x v^{\text {ieme }}$ siècle, Paris, 1955; M. G. Albertini Ottolenghi, "La biblioteca dei Visconti e degli Sforza: gli inventari del 1488 e del 1490", Studi 
petrarcheschi, n. s. 8 (1991) p. 1-281; and contrast the information for Florence in E. Piccolomini, "Inventario della libreria medicea privata compilato nel 1495" Archivio storico italiano, 20, 1874, p. 51-94, and Everson, The Italian Romance Epic, p. 150-151.

15. On Franco-Italian generally and Franco-Venetian literature see A. Roncaglia, "La letteratura franco-veneta", Storia della letteratura italiana, ed. E. Cecchi and N. Sapegno, vol. 2 Il Trecento, Milan, 1965, p. 727-759; L. Renzi, "Il francese come lingua letteraria e il franco-lombardo. L'epica carolingia nel Veneto", Storia della cultura veneta I: Dalle origini al Trecento, ed. G. Folena and G. Arnaldi, Vicenza, Neri Pozza, 1976, p. 563-589; G. Holtus, "L’État actuel des recherches sur le franco-italien: corpus de textes et description linguistique", La Chanson de geste: Écriture, Intertextualités, Translations, ed. F. Suard, Nanterre, Littérales 14, 1994, p. 147-171; Cultura dell'Italia padana e la presenza francese nei secoli xiii-xv, ed. L. Morini, Alessandria, Edizioni dell'Orso, 2001. When constructing stemma for particular narratives, as Catalano did for the Spagna narratives, it is essential to bear in mind the caveats noted here; v. La Spagna, poema cavalleresco del secolo xiv, ed. M. Catalano, 3 vols, Bologna, Commissione per i Testi di Lingua, 1939-40. Note also that compositions in Franco-Italian continued to be produced in northern Italy until into the fifteenth century: see for example Aquilon de Bavière. Roman franco italien en prose, ed. P. Wunderli, Tübingen, Niemeyer, 1982.

16. These are conventionally referred to as $\mathrm{V} 4, \mathrm{~V} 6, \mathrm{~V} 7, \mathrm{~V} 8, \mathrm{~V} 10, \mathrm{~V} 13, \mathrm{~V} 19$ and $\mathrm{V} 20$. V8 contains a version of the Aliscans, V10 Gui de Nanteuil, and V19 and 20 texts of the cycle d'Orange including Fouque de Candie.

17. The manuscript contains the texts of Bovo d'Antona, Berta da li pè grandi, Karleto, Berta e Milon, Enfances Ogier, Rolandin, Chevalerie Ogier and Macaire. For modern editions see La "Geste Francor" di Venezia, edizione integrale del codice XIII del fondo francese della Marciana, ed. and introd. by A. Rossellini, Brescia, Editrice la Scuola, 1986; St. Mark's Ms XIII: Edition and concordance, ed. L. Zarker Morgan, Edwin Mellen Press, ca 2000. See also A. Adler, "The Structural Meaning of Berta da li pè grandi”, Italica, 27, 1950, p. 101 ff.; R. M. Ruggieri, "Berta da li pè grandi”, L'influsso francese in Italia nel Medioevo, ed. R. M. Ruggieri, Rome, Edizioni De Sanctis, 1969; A. Franceschetti, “Appunti sui cantari di Milone e Berta e della nascita di Orlando", Giornale storico della letteratura italiana, 152, 1975, p. 387-399; L. Z. Morgan, “Ogier le danois in the Geste Francor: 'Chevaleries', the Maganzesi and incompetent Kings", L'épopée romane au Moyen Âge et aux temps modernes. Actes du $x i v^{\text {ieme }}$ Congrès international de la Société Rencesvals pour l'étude des épopées romanes, Naples 24-30 juillet 1997, ed. S Luongo, 2 vols, Naples, Fridericiana Editrice Universitaria, 2001, I, p. 335-351.

18. See G. Vidossi, "Letteratura franco-italiana", Le Origini, Testi latini, italiani provenzali e francoitaliani, ed. A. Viscardi, Milan-Naples, Ricciardi, 1956, p. 1053-1057. Among the modifications stressed by Vidossi are the hostility and malice of the whole house of Maganza (not just of Gano) and the emphasis on the family life and troubles of Charlemagne rather than the great military exploits and campaigns. See also L. Z. Morgan, "Berta ai piedi grandi: historical figure and literary symbolism", Olifant, 19, 1994-95, p. 37-56 on the modifications to the character of the older Berta and the distinctively Italian emphasis on her deformity, her equal culpability, together with her Maganzese substitute, for the deception of Pepin on the wedding night; $\mathrm{K}$. $\mathrm{H}$. Bender, "Les métamorphoses de la royauté de Charlemagne dans les premières épopées francoitaliennes", Cultura neolatina, 21, 1961, p. 167-174, for the ways in which these texts modify the portrait of the emperor; H. Krauss, Epica feudale e pubblico borghese. Per la storia poetica di Carlomagno in Italia, Padua, Liviana, 1980, for the influence of the social and cultural environment in provoking changes to the textual narratives. For a summary of developments in this area, see Roland and Charlemagne in Europe: essays on the reception and transformation of a legend, London, King's College London Medieval Studies 12, 1996, in particular M. Dorigatti, "Reinventing Roland. Orlando in Italian literature", ibid., p. 105-126; and Everson, The Italian Romance Epic, p. 33-35.

19. For early studies on the Ogier tradition in Italy see P. Rajna, "Uggieri il Danese nella letteratura romanzesca degl'italiani”, Romania, 2, 1873, p.153-169; 3, 1874, p. 31-77; 4, 1875, 
p. 398-436; B. Sanvisenti, "Sul poema di Uggieri il Danese", Memorie della Reale Accademia delle Scienze di Torino, Classe di scienze morali, storiche e filologiche, ser. II, vol. 50, 1901, p. 151-226; and more recently K. Togeby, Ogier le Danois dans les littératures européennes, Munskgaard, 1969, p. 123-33; 173-80; 204-13. Studies on Ogier narratives in Italy can now benefit from the recent critical edition, I "Cantari del Danese", ed. by S. Furlati, Alessandria, Edizioni dell'Orso, 2003. On intriguing aspects of the Italian tradition, see Romanzo cavalleresco inedito (British Library Add. MS 10808), ed. by A. Forni Marmocchi, Bologna, Pàtron, 1989, dealing with both Uggieri and his son Dudone dalla Mazza; M. Villoresi, "Per lo studio delle relazioni fra il Danese e la Regina Ancroia e altri casi di intertestualità nel romanzo cavalleresco del Quattrocento", Interpres, 14, 1994, p. 107-151.

20. See the studies of Daniela Delcorno Branca, "Fortuna e trasformazioni del Buovo d'Antona", Testi, cotesti e contesti del franco-italiano. Atti del primo simposio franco-italiano, Bad-Hoburg 13-16 aprile 1987, In memoriam Alberto Limentani, Tübingen, Niemeyer, 1989, p. 285-306; P. Rajna, "Frammenti di redazioni italiane del Buovo d'Antona", Zeitschrift für romanische Philologie, 11, 1887, p. 153-184; 12, 1888, p. 463-510; 15, 1891, p. 47-87; and Id., Richerche intorno ai "Reali di Francia", Bologna, 1872. For the woodcut tradition see N. Harris, Bibliografia dell' "Orlando Innamorato", 2 vols, Modena, Panini, 1988-91, I, p. 44

21. See A. D'Ancona, "Le tradizioni carolingie", cit.

22. ““'(Dopo la dolorosa rotta quando)"/nella sua Comedìa, Dante qui dice,/e mettelo con Carlo in ciel felice."

23. Interestingly Ganelon is still referred to by Dante with the Franco-Italian form of his name, (Ganellone) rather than Gano as becomes standard in the Italian tradition.

24. A. Viscardi, "canzoni di gesta", Enciclopedia Dantesca, dir. U. Bosco, 6 vols, Rome, Istituto dell'Enciclopedia Italiana, 1970-78, I, p. 809-812.

25. L'Entrée d'Espagne: chanson de geste franco-italien, ed. A. Thomas, 2 vols, Paris, Firmin Didot, 1913; A. Limentani, L“Entrée d'Espagne" e i Signori d'Italia, ed. M. Infurna and F. Zambon, Padua, Antenore, 1992; Id., "L'epica in 'lengue de France': l'Entrée d'Espagne e Niccolò da Verona”, Storia della cultura veneta, cit., II, Il Trecento, p. 338-368; G. Folena, "La cultura volgare e l'umanesimo cavalleresco nel veneto", cit., p. 145; R. Specht, "L'état actuel des recherches sur l'Entrée d'Espagne", Essor et fortune de la chanson de geste dans l'Europe et l'orient latin. Actes du ix eme Congrès international de la Société Rencesvals, Padua-Venice 29 Aug-4 Sept 1982, ed. A. Limentani et al., Modena, Mucchi, 1984, p. 791-794.

26. See Claudia Boscolo, unpublished PhD thesis, University of London, 2005.

27. See the evidence provided for the Este library by G. Bertoni, La biblioteca Estense cit., and Id., "Un copista del marchese Leonello, Biagio Bosoni da Cremona", Giornale storico della letteratura italiana, 72, 1918, p. 96-106; J. E. Everson, The Italian Romance epic, ch. 5, p. 146 ff; and Id., "Read what I say and not what I read", p. 38-40.

28. F.di Ninni (ed.), Niccolò da Verona. Opere, Venice, Marsilio Ed., 1992.

29. For the history of editions of Agostini's continuations, and their links to Boiardo's original poem see N. Harris, Bibliografia dell'“Orlando Innamorato", I, p. 33-42, 46-50, 73-81, 87-90, 96-107, 110-128; II, p. 59-96.

30. See, for example, on Marfisa, the poems of Giambattista Dragoncino (Marfisa bizarra, $1531 \mathrm{ff}$ ), Pietro Aretino (Due, and Tre primi canti di Marfisa, ca $1537 \mathrm{ff}$ ); on Astolfo the poems of Marco Guazzo (Astolfo borioso, $1523 \mathrm{ff}$ ) and Antonio Legname (Astolfo innamorato, $1532 \mathrm{ff}$ ); and on Angelica those of Pietro Aretino (Delle lagrime di Angelica, $1533 \mathrm{ff}$ ) and Vincenzo Brusantino (Angelica innamorata, $1550 \mathrm{ff}$ )

31. See Vidossi, op.cit. p. 1186-1187 quoting Crescini. In introducing Desiderius, the Italian author is in fact respecting historical fact rather more closely than is the case in the Entrée or in many other narratives. 
32. M. Catalano, La Spagna in rima, ed. cit. For a useful discussion of the problem of manuscripts and their contents see R. M. Ruggieri, “Dall'Entrée d'Espagne e dai Fatti di Spagna alla 'materia di Spagna' dell'inventario Gonzaghesco", Cultura neolatina, 21, 1961, p. 182-190.

33. The principal prose narrative is: Li fatti di Spagna, Testo settentrionale trecentesco già detto Viaggio di Carlo Magno in Ispagna, ed. R. M. Ruggieri, Modena, Società tipografica modenese, 1951.

34. Catalano is thus driven to posit a series of lost witnesses, both prose and verse, in the transmission of the tale from the Entrée to the Spagna in rima, in which the four earliest manuscripts of the Spagna in rima descend from two distinct archetypes, while the printed editions of the later fifteenth century depend on lost manuscripts and not on those which now survive. In this hypothesis, the Spagna in rima of the fifteenth century descends equally from the original Entrée; from a reworking of the same, possibly in prose; from a version of the Chanson de Roland; from the Fatti diSpagna in prosa (Viaggio di Carlo Magno); and from an earlier ottava rima version; see La Spagna, ed cit., intro.; see also the contribution to this debate of A. Limentani, "Il racconto epico: funzioni della lassa e dell'ottava", L'Entrée d'Espagne”, cit., p. 243-272, sp. 259 ff.

35. "Orlando". Die Vorlage zu Pulcis Morgante, ed. J. Hübscher, Ausgaben und Abhandlungen aus dem Geibete der Romanischen Philologie, 60, Marburg, Elwert, 1886. There has been much critical discussion in the last 15 years about the precise relationship of Pulci's text to the Orlando, for a summary of which see M. Davie, Half-serious Rhymes. The narrative poetry of Luigi Pulci, Dublin, Irish Academic Press, 1998. The most controversial view is that of P. Orvieto, who considers the Orlando to be a later work than the Morgante, a poor rewriting of it, for which see "Sul rapporto Morgante-Orlando laurenziano", Ritterepik der Renaissance: Akten des deutsch-italienischen Kolloquiums, Berlin 30 Mar-2 Apr. 1987, ed. K. W. Hempfer, Stuttgart, Steiner, 1989, p. 145-153. Orvieto's thesis has recently been convincingly challenged by M. C. Cabani.

36. The Italian Aspromonte texts depend on Franco-Italian manuscripts of the Gonzaga collections, in particular V6 and V7, but in Fassò's analysis the Italian poetic tradition also reveals the influence of a third Franco-Italian manuscript tradition (c) and reflects the two distinct French traditions of this narrative, v. Cantari di Aspramonte inediti, ed. by A. Fassò, Bologna, Commissione per i Testi di Lingua, 1981, intro. p. 1-lvi, esp. p. xii-xviii, xlviii.

37. As with the Entrée d'Espagne, so here too, only one manuscript of the Cantari di Aspramonte survives, datable, like the Spagna in rima, to the second quarter of the fifteenth century. See Fassò, ed. cit. p. liii-lvi.

38. For this reason Fassò dates the surviving ottava rima poem no later than the turn of the fifteenth century. His conclusion, which is less contentious than that of Catalano in respect of the Spagna, nevertheless usefully supports Catalano's assertion of a lost, probably shorter, Spagna cantare from the end of the fourteenth century. The dating of the Spagna in rima, and of the cantari in general has sparked considerable critical debate: see in particular, C. Dionisotti, "Entrée d'Espagne, Spagna, Rotta di Roncisvalle", Studi in onore di Angelo Monteverdi, Modena, Società tipografica editrice modenese, 1959, I, p. 207 ff.; A. Balduino, "Letteratura canterina", cit. p. 67-69, and the summary and bibliography in Everson, The Italian Romance Epic, p. 116-119.

39. See Andrea da Barberino, L' 'Aspromonte" romanzo cavalleresco inedito, ed. crit. con glossario, ed. M. Boni, Bologna, Antiquaria Palmaverde, 1951; and ed. L. Cavalli, Naples, 1972; for the printing history of Aspromonte narratives, see Beer, Romanzi di cavalleria, p. $330 \mathrm{ff}$. but in this respect attention should be given to Dionisotti's reservations about the conclusions she draws concerning the transmission and circulation of cantari -see his "Appunti su cantari e romanzi", Italia medievale e umanistica, 32, 1989, p. 227-261.

40. See Morg. I, 13; O. I. I, xvi, 15-16; O. F. XII, 43, and XXVII, 54: “...la spada soprana / che già d'Orlando fu, [...] / Quando nel pome scritto Durindana / Vide, e 'l quartier ch'Almonte aver solia / Che a quel meschin fu tolto ad una fonte / Dal giovinetto Orlando in Aspromonte."

41. The Turkish landings at Otranto, in 1480 , and the campaigns on the southern Italian mainland created a climate of extreme anxiety and terror among the Italian states. 
42. See again Beer, p. 330, 336, 348; including the two editions of the late sixteenth century by G. M. Verdizzotti $(1591,1594)$; there are two fifteenth-century editions of poems on the subject, making eleven in all.

43. See the conflicting views of the Ottimo commento, Pietro di Dante and Benvenuto, on the one hand, and those of Jacopo della Lana, L'anonimo, Buti and Landino, on the other, summarized by E. Pispisa in Enciclopedia Dantesca, cit., III, p. 313.

44. See E. Levi, “Cantari leggendari”, cit., p. 8-9.

45. Andrea da Barberino, I nerbonesi, in Romanzi dei Reali di Francia, cit.; Le storie nerbonesi, romanzo cavalleresco del secolo xiv, ed. I. G. Isola, Bologna, Romagnoli, 2 vols, 1877 and 1887. See also G. Allaire, "Due inediti di Andrea da Barberino nella Biblioteca Palatina di Parma", Pluteus, 8-9, 1990-1998, p. 19-25.

46. I Cantari di Rinaldo da Monte Albano, ed. E. Melli, Bologna, Commissione per i Testi di Lingua, 1973; Filologia romanza e cultura medievale: studi in onore di E. Melli, ed. A. Fassò, 2 vols, Alessandria, Edizioni dell'Orso, 1998.

47. See for example the interesting discussion by A.Varvaro, "I 'Fiz Aymon' sepolti a Napoli", Medioevo romanzo, 24, 2000, p. 82-91.

48. Melli, ed. cit., intro. p. vii-xxiii. The prose Storie di Rinaldo not only influenced the development of the cantari on the same theme, but also that of other narrative strands - see M. Villoresi, "Supplemento d'indagine su Dodone e altre notizie sui figli di Uggieri il Danese", Interpres, 15, 1995-96, p. 378-406.

49. On this see L. Caretti, Ariosto e Tasso, Turin, 1970, $2^{\text {nd }}$ ed., 1977.

50. For a discussion of the significance of ottava rima, and summary of critical views about the origins of this metre, see Everson, The Italian Romance Epic, cit. p. 113-122.

51. The commentary was composed by Pier Andrea de'Bassi, MS Codex D524 now in the Biblioteca Ambrosiana, Milan; Limentani, Teseida, ed. cit., intro. indicates the existence of 62 manuscripts of the Teseida from the fourteenth to fifteenth centuries; the first printed edition is Ferrara, A. Carnerius, 1475.

52. On early cantari such as Florio e Biancifiore, see A. Balduino, "Letteratura canterina", cit.; D. De Robertis, "Cantari antichi", Studi di filologia italiana, 28, 1970, p.67-175; A. Franceschetti, "Rassegna di studi sui cantari", Lettere italiane, 25, 1973, p. 556-574; I cantari: struttura e tradizione, ed. M. Picone and M. Bendinelli, Florence, Olschki, 1984; and Everson, The Italian Romance Epic, p. 114-115.

53. For studies on this important figure in fourteenth-century Florentine culture see G. Volpi, Il Trecento, Milan, 1912, p. 215-216; and Florence on the Eve of the Renaissance, Acts of the international conference Montreal, 22-23 Oct. 2004, ed. M. Bendinelli Predelli, forthcoming - the majority of the contributions were concerned with Pucci. See also my summary in The Italian Romance Epic, p. 356-359.

54. For a summary of this part of the tradition and relevant bibliography, see my The Italian Romance Epic, p. 41-51, 115-116 ; also my forthcoming article, "Materia di Roma e ottava rima nella seconda metà del Trecento", Florence on the Eve of the Renaissance, cit.

55. See Everson, The Italian Romance Epic, p. 147-148.

56. For the tradition of cantari recitations in Tuscany, see Levi, "Cantari leggendari" cit., p.12; and on the circulation question see G. Folena, "Cultura volgare", cit., p. 150; Domenico Scolari, who came from Tuscany, for example, was probably resident in or near Treviso at the time of composing his ottava rima poem Istoria Alexandri Regis, see J. Storost, Studien zur Alexandersage in der älteren Italienischen Literatur: untersuchungen und texte, Halle, Niemeyer, 1935.

57. Luigi Pulci, Il Morgante, ed. F. Ageno, Milan-Naples, Ricciardi, 1955; for studies on Pulci see G. Getto, Studio sul "Morgante", Como, Marzorati, 1944; G. Mariani, Il "Morgante" e i cantari trecenteschi, Florence, Le Monnier, 1953; D. De Robertis, Storia del "Morgante”, Florence, Le Monnier, 1958; S. Carrai, Le Muse dei Pulci. Studi su Luca e Luigi Pulci, Naples, 1985; C. Jordan, Pulci's "Morgante". Poetry 
and History in fifteenth-century Florence, London-Toronto, Associated Universities Press, 1986; Davie, Half serious Rhymes, cit.; and bibliographical summaries in E. A. Lèbano, "Cent'anni di bibliografia pulciana, 1883-1983”, Annali d'italianistica, 1 (1983), p. 55-79; Id., “Un decennio di studi pulciani, 1984-1994", Annali d'italianistica, 12 (1994), p. 233-265.

58. Morg. XXV, $115 \mathrm{ff}$, and discussion by Davie, Half serious Rhymes, p. 145-149; cf. also Morg. XXVIII 128-29, $143 \mathrm{ff}$.

59. C. Dionisotti, "Fortuna e sfortuna del Boiardo", Il Boiardo e la critica contemporanea. Atti del convegno di studi su M. M. Boiardo, Scandiano-Reggio Emilia 25-27 Apr. 1969, ed. G. Anceschi, Florence, 1970, p. 221-241.

60. See note 35 supra.

61. See Davie, op. cit., p. 20-21, 33-63; and the summary of narrative content and structure in Jordan, op. cit., p. 49-63.

62. Cf. for Pulci's cultural links generally Jordan, op. cit. p. 27-42; Everson, The Italian Romance Epic, p. 122-124; and for these episodes, Davie, op. cit. p. 65-74; 146-148; Jordan, op. cit. p. 141-155.

63. For a discussion of this see Davie, op. cit., p. 146-169; Jordan, op. cit., p. 17-27.

64. D. Acciaiuoli, Vita Caroli Magni, in J. B. Mencke, Scriptores Rerum Germanicarum, 3 vols, Leipzig, Martini, 1728-30, I, cols 813-832.

65. See Everson, The Italian Romance epic, p. 315-316.

66. There has been a great deal of critical work on Boiardo from the mid-twentieth century on and the Innamorato continues to attract the attention of scholars of the epic both in Italy and beyond. See especially Il Boiardo e la critica contemporanea. Atti del convegno di studi su M. M. Boiardo, Scandiano-Reggio Emilia 25-27 April, 1969, ed. G. Anceschi, Florence 1970; Il Boiardo e il mondo estense nel Quattrocento. Atti del convegno di studi Scandiano-Modena-Reggio Emilia-Ferrara, 13-17 Sept. 1994, ed. G. Anceschi and C. Matarrese, 2 vols, Padua, Antenore, 1998; C. Badini, "Rassegna boiardesca (1976-1987)", Lettere italiane, 40, n. 2, 1988, p. 281-296; A. Franceschetti, L“'Orlando Innamorato" e le sue componenti tematiche e strutturali, Florence, Olschki, 1975; and more recently M. Praloran, "Meraviglioso artificio". Tecniche narrative e rappresentative nell"“Orlando Innamorato", Lucca, Pacini Fazzi, 1990; R. Donnaruma, Storia dell'"Orlando Innamorato". Poetiche e modelli letterari in Boiardo, Lucca, Pacini Fazzi, 1996; see also the most recent critical edition, L'innamoramento de Orlando, ed. by A. Tissoni Benvenuti and C. Montagnini, 2 vols, Milan-Naples, Riccardo Ricciardi, 1999.

67. For the life of Boiardo, see Dizionario Biografico degli Italiani, dir. by A. M. Ghisalberti, Rome, Istituto della Enciclopedia italiana, vol. 11, 1969, p. 211-223; and on Boiardo and the Este court, M. Praloran, "Matteo Maria Boiardo", Storia di Ferrara, vol. 7 Il Rinascimento, La Letteratura, Ferrara, 1994, p. 214-264.

68. This is comprehensively surveyed in N. Harris, Bibliografia cit. It was not until Panizzi's edition of 1830 that Boiardo's text was restored to the reader, and only in the later twentieth century that the complete restoration of the text has been achieved with the edition of Tissoni Benvenuti and Montagnini, cit. supra note 66.

69. See "Fortuna e sfortuna", cit. supra note 59.

70. Cf. again Bertoni, La biblioteca estense, cit.

71. Boiardo had translated Herodotus Histories. A manuscript of the Argonautica of Apollonios Rhodes had been brought into Italy by Giovanni Aurispa in 1423. Aurispa spent the last years of his life in Ferrara, dying there in 1459 and both he and his library would have been well known to Boiardo. Narratives on Alexander, in both prose and verse, were enjoying a renewed popularity as Beer's list of printings indicates, v. op. cit., p. 329 ff. Prose narratives were circulating in print as early as 1474 .

72. Astolfo is one of the most fascinating characters of the Italian chivalric tradition and an important Italian development. He is frequently cast as a foil to Orlando and as an accidentprone, comic figure; see esp. on this M. Santoro, "L'Astolfo ariostesco: homo fortunatus", Filologia e letteratura, 9, 1963, p. 236-287. The court setting allows Boiardo to recall the principal female 
figures of the same tradition: Galerana, Clarice, Alda and Ermellina - none of whom play any significant part in the narrative - O. I. I, i, 22.

73. See for example, Libro della Regina Ancroia (printed editions from $1479 \mathrm{ff}$ ), on which see also A. Montanari, "Il libro dell'Ancroia", Libri e Documenti, 18 n. 3, 1993, p. 1-15; Bradiamonte sorella di Rinaldo (1489 ff), Antea Regina (mid-sixteenth century ff) and for Marfisa see note 30 supra; for critical studies on women in Italian Carolingian epic see M. Tomalin, The Fortunes of the Warrior Heroine in Italian literature. An index of emancipation, Ravenna, Longo, 1982; M. Günsberg, “'Donna liberata'? The portrayal of women in the Italian Renaissance Epic”, The Italianist, 7, 1987, p. 7-35; W. Feinstein, "Bradamante in love: some post-feminist considerations on Ariosto", Forum italicum, 22, 1988, p. 48-59; G. Petrocchi, "Guerriere a cavallo", Critica letteraria, 16, 1988, p. 259-262; M. Villoresi, "Le donne e gli amori nel romanzo cavalleresco del Quattrocento", Filologia e critica, 23, 1998, p. 3-43.

74. Beer gives the first printed edition as Bradiamonte sorella di Rinaldo, Florence, 1489, but see her comments, op. cit. p. 230-231 on the pre-existing cantare tradition.

75. Marfisa is a classic virago, uninterested in love or relationships with men, an indomitable fighter, of fiery and martial temper and outstanding heroism and vigour. There is in fact little that is female or feminine in her portrait; see T. P. Roche, Jr, "Ariosto's Marfisa or Camilla domesticated", Modern Language Notes, 103, 1988, p. 113-133.

76. Francesco Petrarca, L'Africa, ed. N. Festa, Florence, Sansoni, 1926; W. Ludwig, Die Borsias des Tito Strozzi: Ein lateinisches Epos der Renaissance, Munich, Wilhelm Fink Verlag, 1977; see also "Tito Vespasiano Strozzi, Origo estensium principium ex Titi Strozzae Borsiade excerpta", in G. Bertoni, Nuovi studi su M. M. Boiardo, Bologna, Zanichelli, 1904.

77. See Everson, The Italian Romance Epic, p. 316-319.

78. Boiardo has little opportunity to develop the dynastic theme before the abrupt termination of his poem, and establishes only the mutual pledge to marry between Ruggiero and Bradamante, and the forecast of Ruggiero's early death. It is left to Ariosto to continue the story up to the marriage, in the Furioso, and to new campaigns which are intended to conclude with Ruggiero's death through Gano's treachery in the Cinque Canti, though Ariosto breaks off his own "continuation" without narrating this tragedy.

79. For a complete list see again Beer, op. cit., p. 335-369. Many of these poems exist only in sixteenth-century editions; one of the most interesting is: Altobello e Re Troiano, for which the earliest extant edition is: Vicenza, per Simon de Gablio ditto Bevilacqua da Pavia, 1491, now in the Bodleian library, Oxford; the first, lost edition is thought to have appeared in 1476.

80. On Cieco see Dizionario Biografico degli Italiani, vol. 49, Rome, Istituto dell'Enciclopedia italiana, 1997-98, p. 715-718 with full bibliography; J. E. Everson, "The Identity of Francesco Cieco da Ferrara", Bibliothèque d'Humanisme et Renaissance, 45, 1983, p. 487-502. The most recent edition, of variable quality, is Il Mambriano, ed. G. Rua, 3 vols, Turin, UTET, 1926; I am currently preparing a new critical edition. For studies on the poem see J. E. Everson, Bibliografia delle edizioni del "Mambriano" di Francesco Cieco da Ferrara, Alessandria, Edizioni dell'Orso, 1994, p. 11-49; Everson, The Italian Romance Epic, cit.

81. For a survey of early criticism on Il Mambriano, see Everson, Bibliografia, cit., p. 39-49.

82. See Dionisotti, "Fortuna e sfortuna", cit.

83. Malagigi (Maugis) became a very popular figure in Italian Carolingian narratives, taking on especially the role of antagonist to Gano and archmanipulator of both Christian and pagan characters; see S. Gugenheim, Il mago Malagigi. Saggio per uno studio sopra la figura del mago nella letteratura cavalleresca italiana, Milan, Tipografia Indipendenza, 1911; O. Pasotti, "Dai cantari ai poemi cavallereschi: prestigio e crisi del mago Malagigi”, La Rassegna della letteratura italiana, 95, 1991, p. 39-48.

84. See my article, "Le Pèlerinage à Compostelle: histoire et littérature à la cour de Ferrare à la fin du quinzième siècle", L'épopée romane, Actes du xv $v^{\text {eme }}$ congrès international de la Société Rencesvals, 
Poitiers 21-27 Aug. 2000, Poitiers, Centre d'études supérieures de civilisation médiévale, 2002, p. $145-155$

85. See my "Les Personnages féminins dans le Mambriano de Francesco Cieco da Ferrara", Charlemagne in the North, Proceedings of the Twelfth International Conference of the Sociéte Rencesvals, Edinburgh 4-11 Aug. 1991, Edinburgh, 1993, p. 281-290; Id., "Sconvolgere gli stereotipi: la caratterizzazione del traditore e della donna guerriera nel Mambriano", Le genre chevaleresque: reception et diffusion, colloque de Bordeaux 17-18 Oct. 2003, ed. J-L Nardone, Toulouse, Collection de l'Écrit, forthcoming; and Id., "Tradizione burlesca nei proemi ai canti del Mambriano",In memoriam Giovanni Aquilecchia, ed. A. Romano, forthcoming; D. Fratani, "L'érotisme dans les nouvelles du Mambriano", Au pays d'Éros, littérature et érotisme en Italie de la Renaissance à l'âge baroque, Paris, 1988, p. 11-52.

86. Discussed in my forthcoming article, "Sconvolgere gli stereotipi", cit.

87. Mamb. XV, 21-24; and O. F. XLIV, 70; XLV, 53-82.

88. For a survey of the printing tradition of these novella see Everson, Bibliografia, cit. p. 235-283 ; for critical studies see Novelle del "Mambriano" del Cieco da Ferrara esposte e illustrate, ed. G. Rua, Turin, 1888; L. di Francia, La novellistica, 2 vols, Milan, Vallardi, 1924, I: Dalle origini al Bandello, p. 568-576; Fratani, art. cit.

89. For a fuller discussion on this topic see A. Franceschetti, "La novella nei poemi del Boiardo e dell'Ariosto", La novella italiana, Atti del convegno di Caprarola, 2 vols, Biblioteca di Filologia e critica III, Rome, 1989, p. 805-840.

90. The novelle are found in Mamb., cantos II, VII, X, XVI, XXI-XXIII, XXV and XXXIX-XL.

91. This novella also forms the basis of Mozart's unfinished opera, L'oca del Cairo, for which see my article, "Fare il becco all'oca: Mozart e il Mambriano di Francesco Cieco da Ferrara", Italianistica, 25, n. 1, 1996, p. 65-81.

92. The problems and uncertain interpretations are summarized in Everson, "Sulla composizione e la datazione del Mambriano",Giornale storico della letteratura italiana, 160, 1983, p. 249-271; see also O. Visani, "La tecnica narrativa dell'esordio nel poema cavalleresco dai cantari all'Ariosto", Schifanoia, 3, 1987, p. 45-84.

93. See eg. XXIV, 1: "Già il bel pianeta che distingue l'ore / Aveva al Tauro infiammate le corna...". For a proemio that almost certainly does refer to a contemporary political event, the French campaigns of 1499-1500, see Mamb. XXXII, 1-2.

94. Fully discussed in Everson, "Tradizione burlesca", cit., forthcoming

95. This is an innovation made by the anonymous poet of the Altobello, for which see A. Perrotta, "Christians and Saracens in Altobello", paper delivered at the Renaissance Society of America conference, Cambridge, 7-9 April 2005, forthcoming.

96. For a survey of criticism on Ariosto and the Orlando Furioso see C. Badini, "Rassegna ariostesca (1975-1985)", Lettere italiane, 38, 1986, p. 104-124; R. J. Rodini and S. Di Maria, Ludovico Ariosto. An annotated bibliography of criticism, 1956-1980, Columbia, University of Missouri Press, 1984; R. J. Rodini, “Selected bibliography of Ariosto criticism, 1980-1987”, Modern Language Notes, 103, 1988, p. 187-203; Id., "Selected bibliography of Ariosto criticism, 1986-1993", Annali di Italianistica, 12, 1994, p. 299-317.

97. On this see esp. C. P. Brand, Ludovico Ariosto: a preface to the "Orlando Furioso", Edinburgh, Edinburgh University Press, 1974; R. M. Durling, The figure of the poet in Reniassance Epic, Cambridge, Mass., Harvard University Press, 1965, ch. 5; D. Delcorno Branca, L'“Orlando furioso" e il romanzo cavalleresco, Florence, Olschki, 1973; D. Javitch, "Narrative discontinuity in the Orlando Furioso and its sixteenth century critics", Modern Language Notes, 103 n. 1, 1988, p. 50-74; and M. Praloran, Tempo e azione nell'“ Orlando Furioso", Florence, Olschki, 1999.

98. See O. F. II, 30; VIII, 29.

99. See Brand, op. cit., ch. 7; Durling, op. cit., ch. 5; C. Carroll, The "Orlando Furioso": a stoic comedy, Tempe, Arizona, University of Arizona Press, 1997. 
100. O. F. VIII, 81-83. The demonic dimension, the sense of possession by spirits and nightmarish visions, is one subsequently much exploited by opera based on the Orlando Furioso; see eg. G. F. Handel, Orlando (1732-33).

101. Cf. Everson, The Italian Romance Epic, cit., ch. 8.

102. As Ariosto's comparison to the battle of Ravenna, 1512, emphasizes: O. F. XIV, 1-10.

103. For a recent discussion of the theme of love in the Orlando Furioso from this perspective, see M. A. Wells, “'Solvite me': Epic, romance and the poetics of melancholy in the Orlando Furioso", Italian Studies, 59, 2004, p. 17-38.

104. See respectively cantos VI-VIII, IX-X, XVI-XVII and XX.

105. See A. Monteverdi, “A proposito delle fonti dell'Orlando Furioso", Cultura neolatina, 21, 1961, p. 259-267. The combat on Lipadusa ends not with the death of Orlando, but of his younger alter ego Brandimarte.

106. O.F XIV, 69-77, though Ariosto's habitual irony is not absent from God's response to the Emperor.

107. See P. Grendler, Books and Schools in the Italian Renaissance, Aldershot, Variorum, 1995; on Tasso's Rinaldo, see M. Sherberg, Rinaldo. Character and Intertext in Ariosto and Tasso, ANMA Libri, Saratoga, California- Stanford University, 1993.

108. T. Folengo, Orlandino I, 21; VI, 2; and VIII, 92-93.

109. T. Tasso, Discorsi dell'arte poetica, Discorsi sul poema eroico, ed. L. Poma, Bari, Laterza, 1964; see also my summary of the problems in The Italian Romance Epic, p.271-278; for an excellent discussion of these tensions and the transition from "poema cavalleresco" to "poema eroico" in the mid-sixteenth century see S. Iossa, Rappresentazione e scrittura. La crisi delle forme poetiche rinascimentali (1540-1560), Naples, Vivarium, 1996, p. 139-333; Id., La fondazione di un genere. Il poema eroico tra Ariosto e Tasso, Rome, Carocci, 2002, p. 25-65; for the subsequent fortuna of the Furioso in the sixteenth century and for various developments in narrative poetry between the Furioso and the work of Tasso, see A. Casadei, La fine degli incanti. Vicende del poema epico-cavalleresco nel Rinascimento, Milan, FrancoAngeli, 1997; D. Javitch, Proclaiming a classic. The canonisation of the "Orlando Furioso", Princeton, Princeton University Press, 1991; D. Looney, Compromising the classics. Romance epic narrative in the Italian Renaissance, Detroit, Wayne State University Press, 1996.

\section{ABSTRACTS}

Les récits épiques sur Charlemagne, Roland et les pairs de France, connus en Italie dès le $\mathrm{XII}^{\mathrm{e}}$ siècle, $\mathrm{y}$ sont récités et copiés en français jusqu'au $\mathrm{XV}^{\mathrm{e}}$ siècle. Cependant, au début du $\mathrm{XIV}^{\mathrm{e}}$ siècle, de nouvelles chansons de geste sont composées sous une forme linguistique hybride, en franco-italien ou en franco-vénitien, notamment dans la vallée du Pô. En Toscane, sous l'influence linguistique de Dante et de Boccace (lui-même auteur d'un récit épique en ottava rima, la Teseida), la mise en italien de ces récits va de pair avec l'invention de ce nouveau mètre, l'ottava rima, qui va bientôt s'imposer dans la poésie narrative italienne.

La mise en prose de ces textes, déjà pratiquée au cours du XIV siècle, culmine avec l'œuvre d'Andrea da Barberino au début du XV $\mathrm{XV}^{\mathrm{e}}$ siècle, avant de perdre de sa consistance. C'est alors au récit en ottava rima que reviennent la transmission et la floraison des chansons de geste dans l'Italie des $\mathrm{XV}^{\mathrm{e}}$ et $\mathrm{XVI}{ }^{\mathrm{e}}$ siècles (à l'époque de la Renaissance et du renouveau de la culture classique). Leur succès est attesté par la quantité de titres produits et les nombreuses 
réimpressions de ces récits épiques. C'est seulement au $\mathrm{XVI}^{\mathrm{e}}$ siècle que ce genre décline; il subsiste dans la culture populaire après avoir joué un rôle d'innovation littéraire de premier plan.

\section{AUTHOR}

JANE E. EVERSON

Royal Holloway University of London 